\title{
Inflammation after spinal cord injury: a review of the critical timeline of signaling cues and cellular infiltration
}

\author{
Daniel J. Hellenbrand, Charles M. Quinn, Zachariah J. Piper, Carolyn N. Morehouse, Jordyn A. Fixel and \\ Amgad S. Hanna* (D)
}

\begin{abstract}
Traumatic spinal cord injury (SCI) is a devastating neurological condition that results in a loss of motor and sensory function. Although extensive research to develop treatments for SCI has been performed, to date, none of these treatments have produced a meaningful amount of functional recovery after injury. The primary injury is caused by the initial trauma to the spinal cord and results in ischemia, oxidative damage, edema, and glutamate excitotoxicity. This process initiates a secondary injury cascade, which starts just a few hours post-injury and may continue for more than 6 months, leading to additional cell death and spinal cord damage. Inflammation after SCl is complex and driven by a diverse set of cells and signaling molecules. In this review, we utilize an extensive literature survey to develop the timeline of local immune cell and cytokine behavior after SCl in rodent models. We discuss the precise functional roles of several key cytokines and their effects on a variety of cell types involved in the secondary injury cascade. Furthermore, variations in the inflammatory response between rats and mice are highlighted. Since current SCI treatment options do not successfully initiate functional recovery or axonal regeneration, identifying the specific mechanisms attributed to secondary injury is critical. With a more thorough understanding of the complex SCI pathophysiology, effective therapeutic targets with realistic timelines for intervention may be established to successfully attenuate secondary damage.
\end{abstract}

Keywords: Spinal cord injury, Inflammation, Secondary cascade, Macrophages, Cytokines, Microglia, Astrocytes

\section{Background}

Every year in North America approximately 12,500 people are paralyzed due to a spinal cord injury (SCI) [1]. After SCI, there is a primary injury caused by the initial trauma, which compromises neurons and glia and initiates a secondary injury cascade that leads to additional cell death and spinal cord damage over the subsequent weeks. This overwhelming inflammatory response in the early phase of injury, combined with the disrupted

*Correspondence: ah2904@yahoo.com

Department of Neurological Surgery, School of Medicine and Public Health (UWSMPH), University of Wisconsin, 600 Highland Ave, Madison, WI 53792, USA blood-spinal cord barrier, progressively adds to spinal cord swelling and damage. The end result in the chronic stage is a dense glial scar leaving patients with a loss of both sensory and motor function below the level of injury [2]. The paralysis often leaves patients unable to care for themselves, exemplifying the need to develop a treatment to help retain or restore function after SCI.

Inflammation after SCI is complex and orchestrated by many cell types and numerous inflammatory cytokines including tumor necrosis factor alpha (TNF $\alpha$ ), interleukin-1 $\beta$ (IL-1 $\beta$ ), and interleukin-6 (IL-6), among several others. Although there are several positive effects from inflammation after SCI, the extensive infiltration of immune cells is a principal contributor original author(s) and the source, provide a link to the Creative Commons licence, and indicate if changes were made. The images or other third party material in this article are included in the article's Creative Commons licence, unless indicated otherwise in a credit line to the material. If material is not included in the article's Creative Commons licence and your intended use is not permitted by statutory regulation or exceeds the permitted use, you will need to obtain permission directly from the copyright holder. To view a copy of this licence, visit http://creativecommons.org/licenses/by/4.0/. The Creative Commons Public Domain Dedication waiver (http://creativeco mmons.org/publicdomain/zero/1.0/) applies to the data made available in this article, unless otherwise stated in a credit line to the data. 
to neural degeneration $[3,4]$. These immune cells are guided to the lesion site from the periphery via cytokines and chemokines released by microglia, astrocytes, and peripherally derived macrophages (PDMs) within the lesion $[5,6]$. Overall, there is a general consensus among scientists regarding the inflammation process after SCI. However, there are discrepancies in the inflammation timeline and the extent of cytokine regulation after injury in the literature. Delineation of precise functional roles of cytokines and their timeline of upregulation/downregulation may provide insight into how to regulate acute inflammatory reactions after SCI [7].

The objective of this review is to conduct an extensive survey of the literature to develop a precise timeline of immune cell and cytokine regulation in the spinal cord after SCI. Here we discuss the injury timeline with a focus on cellular behavior, cytokine activity, and the corresponding changes that occur to the injury site. The majority of studies on inflammation after SCI utilize rodent models. After SCI, mice develop fibrous connective tissue domains throughout the injury site, which differs from rats and other mammals that develop necrotic lesion cavities encased by reactive astrocytes [8-12]. Thus, we will also discuss differences in cytokine profiles observed between rats and mice.

\section{Literature review}

An electronic search of the Medline database for literature describing animal models of SCI from 1946 to 2021 was performed using the following conditions: SCI (MeSH Terms) AND inflammation (MeSH Terms) OR secondary injury (MeSH Terms). For the timeline of local cytokine regulation, the results were further screened and only included articles utilizing rats or mice with uninjured controls or sham controls for comparison of local upregulation or downregulation of cytokines within their experiments (Fig. 1).

\section{Main text}

\section{Inflammation after SCI}

Neuroinflammation is the activation of the central nervous system's (CNS) innate immune system in response to an inflammatory challenge, which is characterized by a host of cellular and molecular changes within the CNS. This inflammation is mediated by the upregulation of cytokines/chemokines (Table 1), which are produced by resident microglia, astrocytes, peripherally derived immune cells, and endothelial cells. Three inflammatory cytokines, TNF, IL-1, and IL- 6 have been studied extensively and are upregulated within hours after the initial injury (Table 1, Figs. 2 and 3). This production in inflammatory cytokines and chemokines results in extensive infiltration of immune cells including microglia, PDMs, and neutrophils, which continue the production of additional inflammatory mediators. Although the degree of neuroinflammation depends on the extent of the primary stimulus or insult, the primary insult often results in an overreaction of the inflammatory process after CNS injury leading to additional cell death [13].

Although the present review focuses primarily on the localized inflammatory response to SCI in rodent models, it is important to note that there is systemic inflammation occurring after SCI. Due to the inability to sample the spinal cord parenchyma of human patients after injury, many are investigating whether human blood serum and/or cerebrospinal fluid (CSF) cytokine samples may be used as biomarkers to provide insight into injury severity, thereby influencing treatment decisions [14-16]. Kwon et al. [14] found that at $24 \mathrm{~h}$ after injury, cytokines IL-6, IL-8, and MCP-1, along with structural proteins, such as GFAP, tau, and S100 $\beta$, were present in significantly higher concentrations than corresponding serum samples in human patients. In the CSF of a rat SCI model $6 \mathrm{~h}$ after injury, TNFa, IL-2, IL-10, IL-17a, and IFN- $\gamma$ concentrations were significantly increased [17], and serum concentrations of TNFa, IL-1 $\beta$, and IL-6 have been shown to remain elevated in rat throughout the first week following SCI [18-20]. This is similar to the local upregulation of these cytokines that occurs within the injured spinal tissue (Figs. 2 and 3). Interestingly, the upregulation of proinflammatory cytokines TNFa and IL- $1 \beta$ persists in the serum 28 days after SCI in a rat, while IL-4 is downregulated at 28 days and there is no significant change in IL-10 at this timepoint [21]. However, Ogurcov et al. [15] found a decreased concentration of both IL-1 $\beta$ and IL-10 in serum of human patients 14 days after SCI. Furthermore, they report the elevation of IL-4 and IFN- $\gamma$ levels at this timepoint [15]. In general, analysis of cytokine in CSF and serum display similar patterns as the local response in injured spinal tissue (Figs. 2 and 3).

Locally, the primary trauma after SCI, injures the glial cells in the spinal cord and damages blood vessels causing ischemia. The death of nearby glial cells and the ischemia are the initial structural and cellular damage that triggers the secondary injury cascade. The primary cytokines that have been studied extensively within this cascade are listed in Table 1 in terms of the cells that secrete them, receptors they bind to, and their effects after SCI. Below, we discuss the timeline of this cascade in terms of cytokine/chemokine regulation and cellular infiltration.

\section{Within the first hour post-injury}

Ischemia, oxidative damage, edema and glutamate excitotoxicity all start minutes after SCI and contribute to substantial secondary damage [22-25]. Cell 


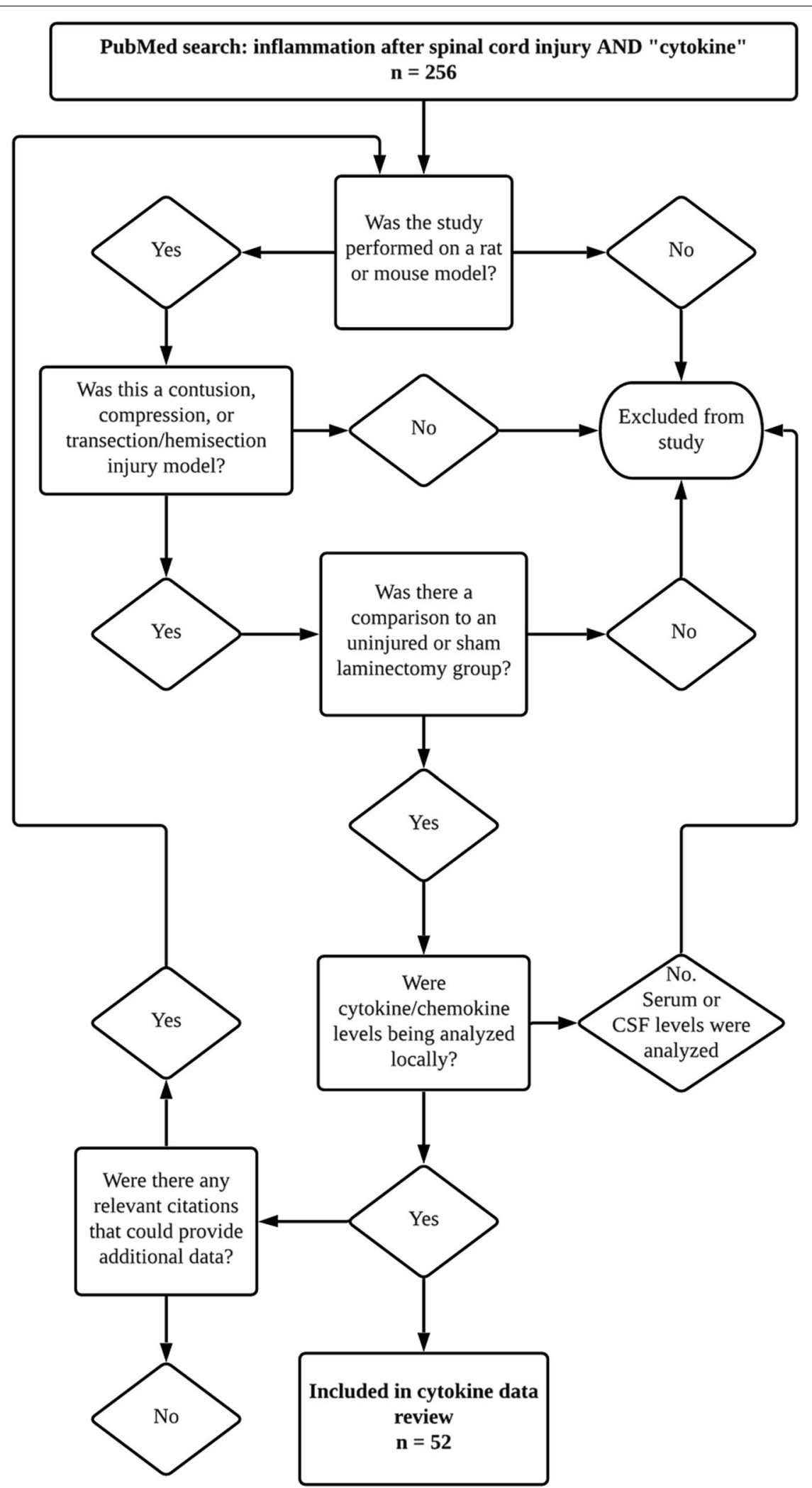

Fig. 1 Flowchart displaying how articles were screened to be analyzed for assessing cytokine/chemokine regulation after SCl. All studies used were performed in rats and mice and assessed local cytokine/chemokine regulation at specific times post-injury compared to uninjured or sham controls 
Table 1 Cytokines and chemokines involved in inflammation after SCl

\begin{tabular}{|c|c|}
\hline $\begin{array}{l}\text { Names } \\
\text { Aliases }\end{array}$ & Cells that secrete the cytokine/chemokine, receptors they bind to, and their effects after SCI \\
\hline $\begin{array}{l}\text { IL-1a } \\
\text { IL-1F1 }\end{array}$ & $\begin{array}{l}\text { Released via activated microglia and PDMs largely in response to disease, infection, or inflammatory events [52] } \\
\text { Binds to IL-1R1 [52] } \\
\text { Required for neutrophil recruitment during cell death-induced sterile inflammation [128] }\end{array}$ \\
\hline $\begin{array}{l}\mathbb{I L}-1 \beta \\
\mathbb{I L}-1 F 2\end{array}$ & $\begin{array}{l}\text { Produced by activated microglia and PDMs as a proprotein, which is proteolytically processed to its active form by caspase } 1 \text { (CASP1/ICE) } \\
{[52,129-131]} \\
\text { Binds to the IL-1R [129] } \\
\text { Plays a more substantial role than IL-1a post-SCI [52, 132, 133] } \\
\text { Stimulates inflammatory mediators including prostaglandins, cyclooxygenase } 2 \text {, and phospholipase A2 }[52,129]\end{array}$ \\
\hline IL-2 & $\begin{array}{l}\text { Produced by activated T-cells [134] } \\
\text { Binds to IL-2R complex, which consists of IL-2Ra, IL-2Rß, and the common } Y \text {-chain subunits [134] } \\
\text { Contributes to the proliferation of T-helpers [87] } \\
\text { Responsible for initiating the proper response of memory T-cells to invading pathogens [135] }\end{array}$ \\
\hline IL-4 & $\begin{array}{l}\text { Produced by T-helper cells, eosinophils, basophils, and mast cells [136] } \\
\text { Binds to IL-4Ra, which will either dimerize with the common cytokine-receptor } \mathrm{Y} \text {-chain and produce the type-1 signaling complex, or with } \\
\text { IL-13Ra1 and produce the type-2 signaling complex [136,53] } \\
\text { Increases microglia/macrophages expressing antigens characteristic of an anti-inflammatory M2 phenotype [70] } \\
\text { Increases the number of oligodendrocytes and neuronal markers } \beta \text { III-tubulin and NeuN after SCl, suggesting a role in neuroprotection } \\
\text { [137] }\end{array}$ \\
\hline IL-5 & $\begin{array}{l}\text { Produced by hematopoietic and non-hematopoietic cells, including granulocytes, T-cells, and natural helper cells [138] } \\
\text { Binds to IL-5R and stimulates B-cell growth as well as increases immunoglobulin secretion (primarily IgA). Is also a key mediator in eosino- } \\
\text { phil activation }[139,140]\end{array}$ \\
\hline IL-6 & $\begin{array}{l}\text { Expressed in astrocytes, microglia and PDMs, and neurons [37] } \\
\text { Binds to IL-6R, which exists either as a membrane-bound receptor or a soluble receptor [141] } \\
\text { Activates inflammation and is a strong recruiter of immune cells after SCI [142] } \\
\text { Acts on neural stem cells to induce their differentiation into astrocytes [143] }\end{array}$ \\
\hline $\begin{array}{l}\text { IL-8 } \\
\text { CXCL8 } \\
\text { GRO(the } \\
\text { rat ana- } \\
\text { logue) }\end{array}$ & $\begin{array}{l}\text { Produced by a wide variety of cells including monocytes, endothelial cells, T-cells, and macrophages [144] } \\
\text { Binds to CXCR1 and CXCR2 receptors [52] } \\
\text { Induces chemotaxis in neutrophils and granulocytes [52] } \\
\text { Upregulated for at least } 14 \text { days after SCl and strongly correlates with the extent of injury }[87,49,38,14]\end{array}$ \\
\hline IL-10 & $\begin{array}{l}\text { Produced by monocytes, B-cells, dendritic cells, natural killer cells, and T-cells [145] } \\
\text { Binds to IL-10R heterotetramer complex made of two IL-10R1 molecules and two IL-10R2 molecules [146] } \\
\text { Downregulates several pro-inflammatory cytokines and inflammatory species [56] } \\
\text { Provides trophic support to neurons through downregulation of pro-apoptotic factors and upregulation of anti-apoptotic factors [56] }\end{array}$ \\
\hline $\begin{array}{l}\text { IL-12 } \\
\text { IL-12a } \\
\text { P35 }\end{array}$ & $\begin{array}{l}\text { Produced by dendritic cells, macrophages, monocytes, neutrophils, microglia cells, and B-cells [147] } \\
\text { Binds to IL-12R, which consists of the IL-12R } 31 \text { and IL-12R } 32 \text { chains [148] } \\
\text { IL-12(p70) expresses nitric oxide synthase and TNFa in microglia and PDMs [149] }\end{array}$ \\
\hline IL-13 & $\begin{array}{l}\text { Produced by T-cells, dendritic cells, and activated Th2 cells [150] } \\
\text { Binds either to IL-13Ra1 or IL-13Ra2 [53, 151] } \\
\text { Involved in the production of transforming growth factor beta (TGF- } \beta \text { ) [151] }\end{array}$ \\
\hline $\begin{array}{l}\text { IL-17a } \\
\text { IL-17 } \\
\text { CTLA-8 }\end{array}$ & $\begin{array}{l}\text { Produced by several types of cells including T-cells, dendritic cells, and macrophages [152] } \\
\text { Binds to the A and C subunits of IL-17R [152] } \\
\text { IL-17 knockout mice showed increased locomotor function after SCI suggesting a role in regulating secondary degeneration of neural } \\
\text { tissue [153] }\end{array}$ \\
\hline $\begin{array}{l}\text { TNF-a } \\
\text { TNF } \\
\text { TNFSF2 }\end{array}$ & $\begin{array}{l}\text { Produced by microglia, PDMs, astrocytes, oligodendrocytes, monocytes, and neurons [37, 39] } \\
\text { Two active forms are transmembrane TNFa and soluble TNFa [154] } \\
\text { Soluble TNFa is released by regulated cleavage of transmembrane TNFa by TNFa-converting enzyme (TACE/ADAM17) [154] } \\
\text { Binds to TNFR1 and TNFR2 [154] } \\
\text { Affects cell proliferation, differentiation, apoptosis, immunity, and inflammation [37] } \\
\text { Recruits macrophages to injury site [37] }\end{array}$ \\
\hline IFN- $\gamma$ & $\begin{array}{l}\text { Produced by } \gamma \delta \text { T-cells and leads to the activation of macrophages }[95,155] \\
\text { Induces secretion of IL-10 from microglia and PDMs }[155] \\
\text { Can act synergistically with GM-CSF to promote the production of cytokines }[156]\end{array}$ \\
\hline $\begin{array}{l}\text { GM-CSF } \\
\text { CSF2 }\end{array}$ & $\begin{array}{l}\text { Produced by macrophages, mast cells, T-cells, fibroblasts, and endothelial cells in response to immune activation and cytokines that medi- } \\
\text { ate inflammation [157] } \\
\text { Causes differentiation of hematopoietic progenitor cells into granulocytes, macrophages, and dendritic cells [158] } \\
\text { Can stimulate the proliferation of bone marrow stem cells and reduce leukocyte apoptosis, as well as cause microglia to proliferate and } \\
\text { change their morphology [158] } \\
\text { GM-CSF-induced activation of microglia may promote functional recovery and axonal regeneration by release of brain-derived neuro- } \\
\text { trophic factor or by phagocytosis of myelin debris }[159,160]\end{array}$ \\
\hline
\end{tabular}


Table 1 (continued)

\begin{tabular}{|c|c|}
\hline $\begin{array}{l}\text { Names } \\
\text { Aliases }\end{array}$ & Cells that secrete the cytokine/chemokine, receptors they bind to, and their effects after SCI \\
\hline $\begin{array}{l}\text { MCP-1 } \\
\text { CCL2 }\end{array}$ & $\begin{array}{l}\text { Secreted by activated T-cells, astrocytes, microglia, and monocytes [161] } \\
\text { Binds to CCR2 [106] } \\
\text { Activates and recruits mononuclear phagocytes, T-cells, and B-cells [162] }\end{array}$ \\
\hline $\begin{array}{l}\text { MIP-1a } \\
\text { CCL3 }\end{array}$ & $\begin{array}{l}\text { Secreted by activated T-cells, astrocytes, microglia, and monocytes [161] } \\
\text { Promotes chemotaxis of monocytes and T-cells [161] } \\
\text { Expression induced by pro-inflammatory stimulators, such as LPS, TNFa and IL-1 } \beta \text {, and neuronal injury [163] } \\
\text { Can enhance the production of other pro-inflammatory cytokines via CCR1, CCR4, and CCR5 [163] } \\
\text { Impacts CNS inflammation through regulation of macrophages and astrocytes [163] }\end{array}$ \\
\hline $\begin{array}{l}\text { RANTES } \\
\text { CCL5 } \\
\text { TCP228 }\end{array}$ & $\begin{array}{l}\text { Produced by astrocytes and is primarily involved in promoting migration of M2 macrophages [51] } \\
\text { Expression induced by IL-1 and macrophage migration inhibitory factor [51] } \\
\text { Binds to CCR1, CCR3, and CCR5 [164] } \\
\text { Associated with T-cell activation in SCI. Chronic T-cell activation subsequently contributes to neurodegeneration and inhibits repair of } \\
\text { injured tissues [165] } \\
\text { Induces the migration and recruitment of a wide variety of cells including T-cells, dendritic cells, natural killer cells, eosinophils, basophils, } \\
\text { mast cells, and endothelial progenitor cells [51] } \\
\text { May help amplify inflammatory response by facilitating the recruitment of inflammatory cells to the injury [51] }\end{array}$ \\
\hline TGF- $\beta 1$ & $\begin{array}{l}\text { Produced by lymphocytes, macrophages, and dendritic cells [166] } \\
\text { Binds to TGF- } \beta R 1, \text { TGF- } \beta R 2 \text {, and TGF- } \beta \text { R3 [167] } \\
\text { Activates glial cells and phagocytes to form connective tissue and extracellular matrix [168] } \\
\text { Influences the differentiation, proliferation, and state of activation of leukocytes [166] } \\
\text { Known to suppress expression of MHC class II antigen [166] }\end{array}$ \\
\hline
\end{tabular}

permeabilization, pro-apoptotic signaling and ischemic injury due to the destruction of the microvascular supply cause additional cell dysfunction and death just minutes after SCI $[26,27]$. There is also intracellular calcium dysregulation in both neurons and glia, resulting in the activation of calpains, which can cause mitochondrial dysfunction and cell death [25, 28, 29]. Microglia, the resident immune cells, quickly respond to the injury and their early response is protective [30-32]. However, microglia rapidly change to proinflammatory cells and release cytokines setting off a cascade of events that lead to an infiltration of peripheral immune cells [12]. The activated microglia retract their cytoplasmic processes and become indistinguishable in terms of morphology from the PDMs, which enter from damaged blood vessels [33-36]. Within 30-min post-injury, microglia and astrocytes begin expressing inflammatory cytokines IL-1 $\beta$ and TNFa mRNA [37]. Pineau and Lacroix showed that TNFa mRNA positive cells, including microglia, astrocytes, oligodendrocytes, and neurons, peaked just $1 \mathrm{~h}$ after mice sustained a spinal cord contusion [37].

\section{Cytokine signaling from 1-h up to 3-h post-injury}

Using colocalization studies for mRNA after SCI in mice, Pineau and Lacroix showed that during the first few hours, proinflammatory cytokines IL-1 $\beta$, TNFa, and IL- 6 were being synthesized by microglia/macrophages, astrocytes, and neurons [37]. Using various techniques to measure $\mathrm{TNF} \alpha$ in these early hours after SCI, five other studies all observed significant increases in TNFa levels (Fig. 2B) [38-42]. There were also five studies that measured IL- $1 \beta$ using various techniques in these early hours after SCI and three of these studies observed a significant increase in IL-1 $\beta$ (Fig. 2A) [38, 40, 41]. However, two experiments utilizing enzyme-linked immunosorbent assays (ELISAs) to measure IL- $1 \beta$ did not observe an increase at this early timepoint $[42,43]$, which may be the result of the discrepancy in time needed to synthesize the full protein and the time needed for it to be proteolytically processed to its active form by caspase 1 [44]. There were very similar trends in the early IL- 6 upregulation to that of IL-1 $\beta$ (Fig. 2C) [38, 40-42]. The proinflammatory cytokines TNFa, IL-1 $\beta$, and IL- 6 are presumed to be the predominant players early in the injury timeline. Thus, these three cytokine levels were the most frequently analyzed in these early hours after SCI (Fig. 2).

\section{Cytokine signaling and cellular reactions from 3-h up to 6-h post-injury}

At this early stage of inflammation, the majority of the literature agrees that the primary inflammatory cytokines, TNFa, IL-1 $\beta$, and IL-6, are all significantly upregulated (Fig. 2) [37, 38, 40, 45-48]. Pineau and Lacroix observed that at $3 \mathrm{~h}$ after SCI in mice, the number of cells expressing the TNFa mRNA transcript at the lesion epicenter was significantly upregulated compared to uninjured controls. However, the number of cells had decreased by $66 \%$ compared with the 1 -h timepoint [37]. Two research groups did not observe a significant increase in TNFa protein expression at $4 \mathrm{~h}$ after a rat contusion, 


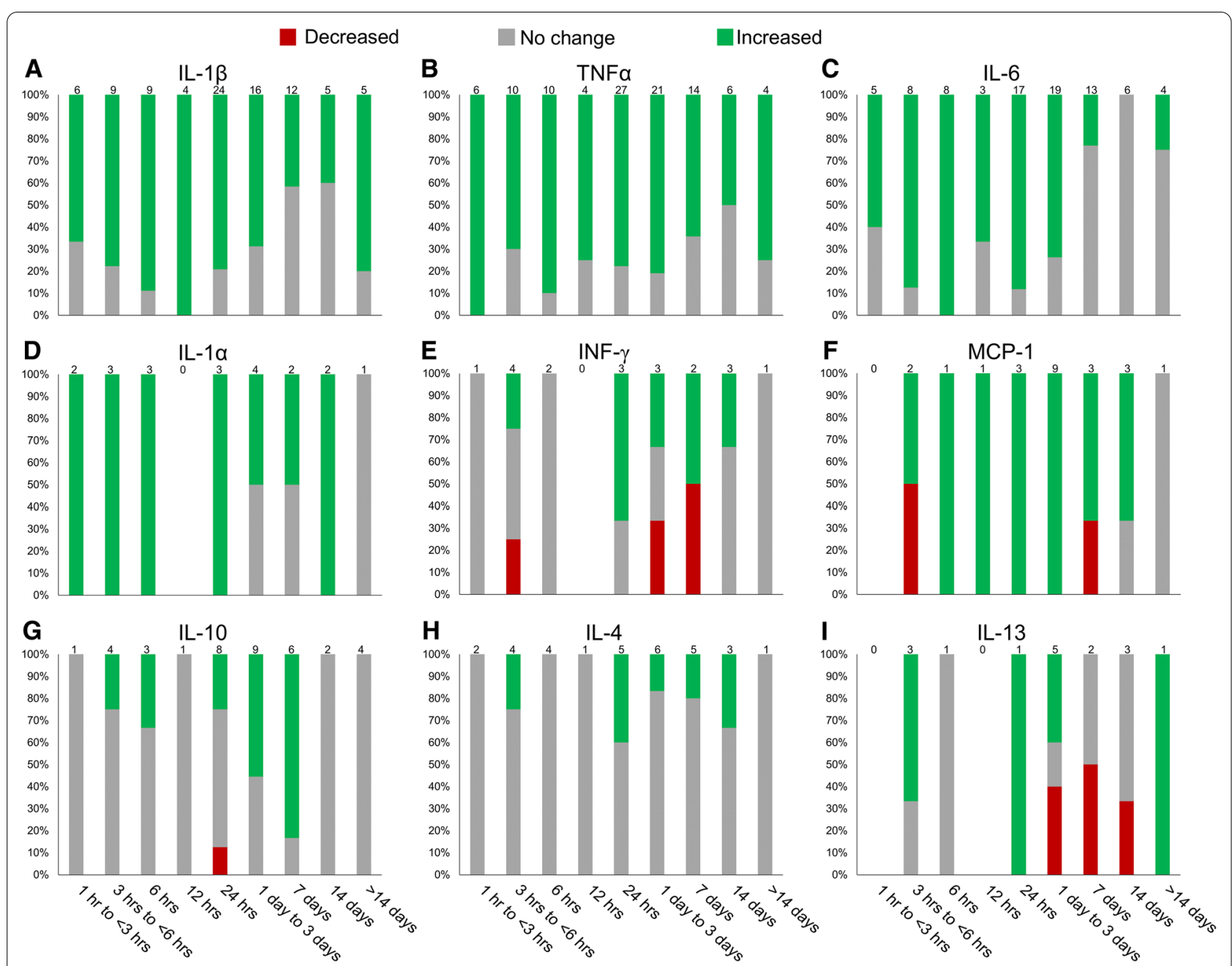

Fig. 2 Depiction of cytokine regulation following SCI in rodent models. A literature search was conducted and relevant data regarding significant cytokine regulation was collected at various timepoints. Data is presented as a percentage of studies that found significant changes in cytokine protein or mRNA expression levels compared to sham or naive controls $(p<0.05)$. The number of papers used for each timepoint is listed at the top of each bar. A Changes in IL-1 $\beta$ levels after SCI $[17,21,37,38,40-43,45-47,66-68,85,87-89,94,106,107,169-187]$. The proinflammatory cytokine IL-1 $\beta$ shows consistent upregulation in the acute phase following $\mathrm{SCl}$. However, there are some discrepancies as to whether IL-1 $\beta$ remains upregulated several days after injury and the second surge 14 days was only observed in mice. B Changes in TNFa levels after SCI [17, 36-42, $45-48,66-69,85,87-89,94-96,107,121,169-180,182-189]$. The majority of studies show an upregulation of the proinflammatory cytokine TNFa immediately following SCl and persisting several days after injury. C Changes in IL-6 levels after SCI $[17,37,38,40-42,45,47,66-68,84,85,87-90,93$, $95,96,107,121,173,174,176,178,183,184,186-189]$. Consistent upregulation of the proinflammatory cytokine is seen in the first $24 \mathrm{~h}$ following injury before returning to baseline levels by 7-day post-injury. D Changes in IL-1a levels after SCI [17, 38, 40, 66, 84, 87, 90, 95]. The proinflammatory cytokine IL-1 a is upregulated in a similar manner to its isoform IL-1 $\beta$, though IL-1 $\beta$ plays a more significant role following SCI [132, 133]. E Changes in IFN- $\gamma$ levels after SCI $[17,38,48,87,90,95]$. The relative change in IFN- $\gamma$ expression following SCI remains controversial, as shown by the conflicting data presented. It appears to be upregulated in mice and downregulated in rats after $24 \mathrm{~h}$. F Changes in MCP-1 levels after SCI [17, 38, 47, 84, 85, $87-90,93,121]$. While there is some debate surrounding the regulation of the MCP-1 chemokine immediately after injury $(1 \mathrm{~h}$ to $<6 \mathrm{~h})$, nearly all data collected shows that MCP-1 expression levels elevate quickly and remain upregulated for several days. G Changes in IL-10 levels after SCI [17, $21,38,46,47,66,85,87-90,96,170,173-176]$. A delayed response is seen with IL-10 showing mixed results until upregulation at 3-7 days after injury. The anti-inflammatory cytokine returns to baseline levels by 14 days. $\mathbf{H}$ Changes in IL-4 levels after SCI $[7,17,38,47,48,66,70,87]$. While some studies show increased expression of the anti-inflammatory IL-4, most researchers did not observe a change in IL-4 levels. I Changes in IL-13 levels after SCI $[17,38,47,48,87,90]$. Previous studies display conflicting data surrounding the regulation of IL-13 after injury, where it was upregulated in mice and downregulated in rats 3 days hours post-injury 


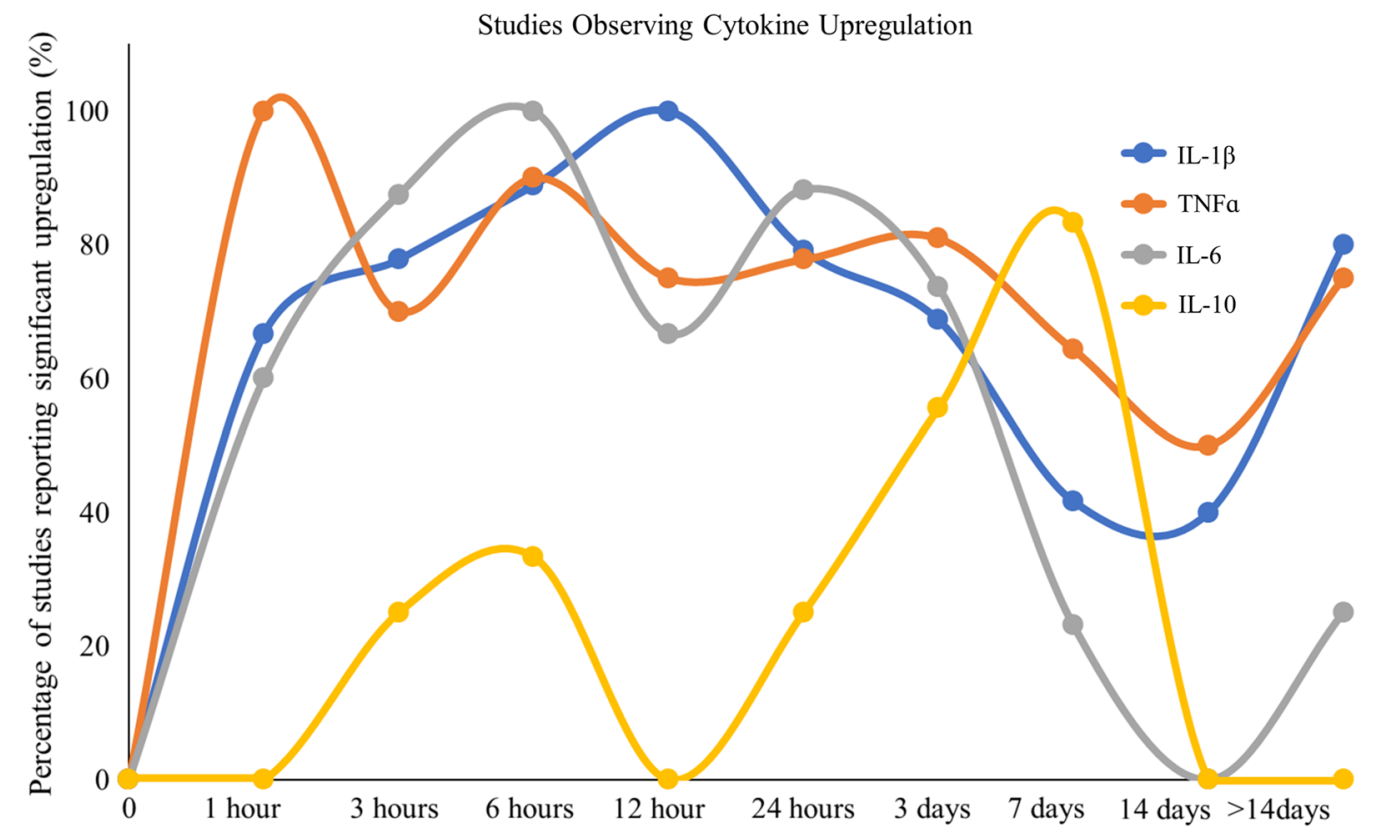

Fig. 3 Line graph displaying the percentage of studies that observed significant upregulation in IL-1 $\beta, T N F a, I L-6$, and IL-10. The majority of investigators observe a significant upregulation of the three most investigated inflammatory cytokines early after injury and TNFa and IL-1 $\beta$ remain upregulated. The anti-inflammatory cytokine IL-10 lags further behind and the majority of investigators show it peaking around 1-week post-injury

which suggests a return to baseline after a rapid onset of TNFa $[38,40]$. Although the upregulation of IL- $1 \beta$ and IL- 6 lags slightly behind that of TNFa and IL-1a, most of the literature agrees that IL- $1 \beta$ and IL- 6 are significantly upregulated within this 3-6-h time window [37, $38,40,42,45-47]$. The expression of growth-related oncogene (GRO), the rat analogue of IL- 8 , is also significantly upregulated at 4 -h post-injury $[38,45,49,50]$. The cytokine regulated upon activation, normal T-cell expressed and presumably secreted (RANTES), which induces migration and recruitment of T-cells, eosinophils, basophils, and leukocytes, has been shown to be significantly upregulated 4-h post-injury, although it is not as prevalent in the literature $[38,47,51]$. This early upregulation in inflammatory cytokines is produced predominantly by microglia and astrocytes and leads to the recruitment of peripheral immune cells.

Although anti-inflammatory cytokines are capable of reducing proinflammatory cytokines, they are generally present at low levels or absent after SCI. IL-4 and IL-13 are related anti-inflammatory cytokines that have been shown to induce alternative macrophage activation [52-55], and IL-10 is an anti-inflammatory cytokine that has been shown to downregulate proinflammatory cytokines [56, 57]. Four hours after SCI in mice, IL-10 was significantly upregulated [47], yet, at this same time post-injury in rats IL-10 was not upregulated $[38,46]$. In contrast, IL-13 was upregulated in rats $[38,48]$ but not in mice [47]. A number of researchers have shown that there are differences in the adaptive immune system between mice and rats as well as between different strains of mice, which may explain the discrepancies in anti-inflammatory cytokine regulation $[12,58-60]$.

The majority of the literature shows that in this 3-6-h post-injury period there is an upregulation in inflammatory cytokines, which are produced largely by local microglia and astrocytes, leading to further recruitment and proliferation of microglia and astrocytes and the recruitment of peripheral immune cells (Fig. 4). Neutrophils begin to appear 4-6 h after SCI and produce oxidative and proteolytic enzymes to sterilize and prepare the area for repair [61, 62]. However, overwhelming numbers of neutrophils result in tissue damage [61].

Lipid peroxidation, the process by which free oxygen radicals react with the polyunsaturated fatty acids of membrane lipids, leads to 4-hydroxynonenal (4-HNE) formation and disrupts cell membrane fluidity, metabolic processes, and ion transport systems [63, 64]. 4-HNE itself is neurotoxic and can bind to cellular proteins and damage their structural and functional integrity [65]. Xiong et al. [65] also observed that byproduct formation such as 4-HNE increases as soon as 3-h postinjury and remains high for 2 weeks. 


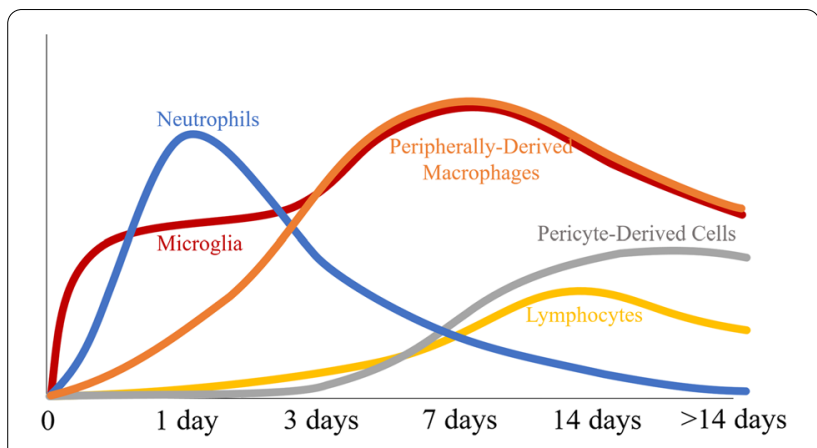

Fig. 4 Primary injury after $\mathrm{SCl}$ causes cell membrane disruption and rupture of blood vessels leading to secondary injury with extensive upregulation of cytokines/chemokines and infiltration of immune cells. Microglia, the resident macrophages, are early responders and become indistinguishable in terms of morphology from peripherally derived macrophages. In rats, neutrophils peak early in the injury at around $24 \mathrm{~h}$ and gradually decrease over the next 7-10 days, while lymphocytes peak at lower levels and at a much later time. Pericytes also infiltrate later and interact with microglia around the edges of the injury and this entire injury site is encased by activated astrocytes

\section{Cytokine signaling and cellular reactions from 6-h up to 12 -h post-injury}

Almost all of the literature shows that the upregulation in proinflammatory cytokines TNFa, IL-1 $\beta$, and IL- 6 continues through the 6-12-h timeframe post-injury (Figs. 2 and 3) [17, 37-39, 41, 42, 66-69]. There is also a significant increase in monocyte chemoattractant protein 1 (MCP-1) [17], macrophage inflammatory protein 1-alpha (MIP-1a) [17], RANTES [17], GRO [17, 50], and C-X-C motif chemokine ligand 1 (CXCL1) [69]. The majority of the literature shows that IL-4, IL-10, and IL-13 remain at baseline levels (Fig. 2G-I) [17, 38, 66, 70]. Ultimately, this inflammatory environment continues the recruitment and proliferation of microglia and astrocytes and the recruitment of peripheral immune cells. Apoptosis from this exacerbated inflammation process after SCI peaks near $8 \mathrm{~h}$ in neurons and around $24 \mathrm{~h}$ in glial cells [71, 72].

During these early hours after injury, polymorphonuclear leukocytes are the predominant infiltrating cells [73], and over-activation of these cells continue to cause tissue destruction through the release of significant amounts of neurotoxins including reactive oxygen species (ROS), reactive nitrogen species (RNS), chemokines, and enzymes [4, 61, 74, 75]. Popovich et al. [32] also showed that lymphocytes begin to accumulate around blood vessels in gray matter as early as $6 \mathrm{~h}$ after SCI in rats.

After SCI, activated microglia and PDMs have the capability to take on different functional phenotypes $[33,57$, 63, 76-80]. Resolution-phase macrophages are enriched with major histocompatibility complex II (MHC) expression [81], express anti-inflammatory cytokines TGF- $\beta 1$ and IL-10 [81, 82], and have elevated expression of key enzymes involved in synthesizing pro-resolving mediators that actively turn off inflammation [83]. In vivo, macrophages in general are not fully inflammatory (M1) or anti-inflammatory (M2), but rather exist on a continuum in which their roles and phenotype are dictated by the extracellular environment [57]. As early as $6 \mathrm{~h}$ after SCI in mice, Kigerl et al. [12] observed antigen-presenting MHCII cells in the dorsal roots, meninges, and within a subset of perivascular spaces.

\section{Cytokine signaling and cellular reactions from 12-h up to 24-h post-injury}

The majority of the literature continues to show elevated levels of TNFa, IL-1 $\beta$, and IL-6 (Fig. 2A-C). There are also increased levels of GRO [50, 84], IL-7 [48], and chemokines MCP-1 [7, 85], and MIP- $1 \alpha$ [84]. IL-4, IL-10, IL-13 and TGF- $\beta 1$ all remain at baseline levels (Fig. 1G-I) $[41,70,85]$. Although IL-4 was not upregulated, FrancosQuijorna et al. [70] observed an upregulation of IL-4Ra on microglia and macrophages.

Cells expressing IL- $1 \beta$ and cells expressing IL- 6 both peaked at 12-h post-injury [37]. Infiltrating leukocytes also produce IL-1 $\beta$, TNFa, IL-6, and LIF 12-h post-injury [37]. The infiltrating neutrophils, which phagocyte and clear debris, secrete proteases, elastase, myeloperoxidase, and release reactive oxygen species, peak at 24-h post-injury [86]. The byproduct formation of 4-HNE also peaked at $24 \mathrm{~h}$ and remained elevated for 2 weeks [65].

\section{Cytokine signaling and cellular reactions from $24 \mathrm{~h}$ up to 7-day post-injury}

Pineau and Lacroix's colocalization studies showed that TNFa mRNA levels 2-day post-injury had returned to the levels detected in mice that had received laminectomy only [37]. The number of IL- $1 \beta$ positive cells continued to decrease at 2-, 4- and 7-day post-injury, and from $24 \mathrm{~h}$ up to 4 days, the average number of cells expressing the IL- 6 transcript progressively decreased to become almost nonexistent at 7 days [37]. Despite the decrease observed in the number of cells expressing mRNA, several researchers observed levels that were significantly higher than their uninjured controls at 1 day (TNFa $77.8 \%$, IL-1 $\beta$ 79.2\%, IL-6 88.2\%), 3 days (TNFa $80.1 \%$, IL-1 $\beta$ 68.8\%, IL-6 73.7\%), and 7 days (TNFa 64.3\%, IL-1 $\beta$ 41.7\%, IL-6 23.1\%) after SCI (Figs. 1 and 2). These trends were similar in the literature for both rats and mice after SCI. GRO was also significantly elevated on day 1 [ 50 , 84], day 3 [84, 87], and day 7 [87].

There is significant upregulation of chemokines throughout this first week recruiting monocytes, T-cells, and dendritic cells to the injury site. MIP- $1 \alpha$ is upregulated on day 1 [84], day 3 [84, 87], and day 7 
[87]. When tested, CXCL1 expression is significantly increased on day $3[69,88,89]$ and day 7 [86] and RANTES is significantly upregulated on day $3[47,88-$ 90]. Previous studies have shown that MCP-1 mRNA is increased in mice 1-day post-injury and returns to baseline before 7-day post-injury [91, 92]. However, here there are some conflicting results 7-day postinjury. Although studies looking at mRNA MCP- $1 \alpha$ levels 7-day post-injury observed a significant increase in mice [93] and rats [85], a study using multiplex assay 7-day post-injury in rats observed a significant decrease in MCP-1 $\alpha$ levels (Fig. 2F) [87]. MIF and COX2 were inducibly expressed after SCI in rats and peak levels were observed on day 4 [94].

Some cytokines displayed contrasting behaviors between rat and mouse models during the 24-h to 7-day period. In mice, IFN- $\gamma$ levels were significantly increased 1 day [48, 95], 3 days [48], and 7 days [48] after injury, but IFN- $\gamma$ levels in rats were significantly decreased at 3 days [87] and 7 days [87] following SCI (Fig. 2E). Levels of IL-2 and IL-5 were significantly decreased in rats on day 3 and day 7 post-injury [87], where in mice there was no change in IL-2 levels [88], and a significant increase in IL-5 levels 3-day post-injury [89]. IL-13 was also significantly decreased 3 days and 7 days after SCI in rats [87]. However, in mice IL-13 was significantly upregulated 1 day and 3 days after SCI $[48,90]$ and returned to baseline levels 7-day post-injury (Fig. 1I) [48]. Similarly, IL-4 levels were not changed 1 day $[38,66], 3$ days $[7,66$, 87], and 7 days [7, 87] after SCI in rats, but were significantly increased 1 day, 3 days, and 7 days post-injury in mice (Fig. 2H) [48].

The majority of researchers did not observe a significant increase in the anti-inflammatory cytokine IL-10 until 3-day post-injury, which remained elevated until 7 days after SCI (Fig. 2G). There were also several researchers that did not observe changes in IL-10 levels after SCI in both mice [90] and rats $[38,66]$. TGF- $\beta 1$ was significantly increased 3-day [41] and 7-day post-injury $[41,96]$.

Using flow cytometry after SCI in rats, Beck et al. [97] demonstrated a time-dependent multiphasic response of cellular inflammation, where the initial phases of cellular inflammation were composed of an early peak of neutrophils 1-day post-injury, followed by a peak of macrophages/microglia 7-day post-injury, and T-cells peaking at 9-day post-injury. This timeline of cellular inflammation in rats with SCI is in agreement with other literature for neutrophils [61, 62], macrophages [62, 98, 99], and lymphocytes [98] (Fig. 4). After SCI in mice, neutrophils enter the injured spinal cord within $6 \mathrm{~h}$, but surprisingly do not reach peak numbers until 14-day post-injury and persist for up to 6-week post-injury [12].
Although axons begin to retract within 2-day postinjury due to the initial trauma, there is a later phase of axon retraction caused by activated macrophages [63, 100-104]. Bisicchia et al. [105] demonstrated that autophagosomes mediating the initiation of autophagy accumulate in axotomized neurons 1 day after SCI and remain high from 3 to 5 days before falling slightly 7-day post-injury. By 5-day post-injury, activated microglia and PDMs are the predominant inflammatory cells, where phagocytic macrophages are mostly located in areas of necrosis and microglia are at the margins. Lendate et al. [99] showed that microglia are highly dynamic, proliferate extensively the first week after SCI, and form a dense cellular interface at the border of the lesion between reactive astrocytes and infiltrating PDMs (Figs. 4 and 5).

\section{Cytokine signaling and cellular reactions from 7-day up to 14-day post-injury}

A second surge was observed in cells expressing $\mathrm{TNFa}$ and IL-1 $\beta$ 14 days after SCI in mice [37]. This second upregulation of TNFa and IL- $1 \beta$ appears to only occur in mice $[37,48,106]$, and not rats [87, 107] (Fig. 2A, B). IL-6 appears to be returning to baseline in both rats and mice by 14-day post-injury [37, $87,90,93$, 107] (Fig. 1C). Mukhumedshina et al. [87] measured cytokine levels 14 days after SCI in a rat and observed a significant increase in IL-1a, GRO, IL-2, and MIP-1a, and a significant decrease in levels of IL-13, IL-2, IL-5, IL-18, IL-17a, and GM-CSF. IL-1a, IL-4, IL-12, IL-15, RANTES, MIP-1a, MCP-1, and IL-7 are significantly upregulated in mice 14-day post-injury [48, 90, 93]. Beyond day 14 post-injury, there is less data measuring cytokine levels for comparison (Fig. 2).

Although there is proliferation of oligodendrocyte progenitor cells and maturation over the first 2-week post-injury, the end result is still improper remyelination [63, 108, 109]. The response of microglia and PDMs are similar after SCI in mice, rats, and humans, where peak numbers are reached around 7-day postinjury and remain in the injury site for months after injury [57, 97-99, 110, 111]. In contrast, lymphocyte infiltration is much larger in mice than in rats or humans and peaks at a much later timepoint (14-day post-injury) in mice $[98,110,111]$. Also unique to mice is the infiltration of fibroblast-like cells and the formation of fibrotic tissue matrix [110]. It is suggested that the infiltration of fibroblast-like cells coupled with the larger T-cell infiltration may be responsible for minimizing the development of cysts in mice $[110,111]$. 


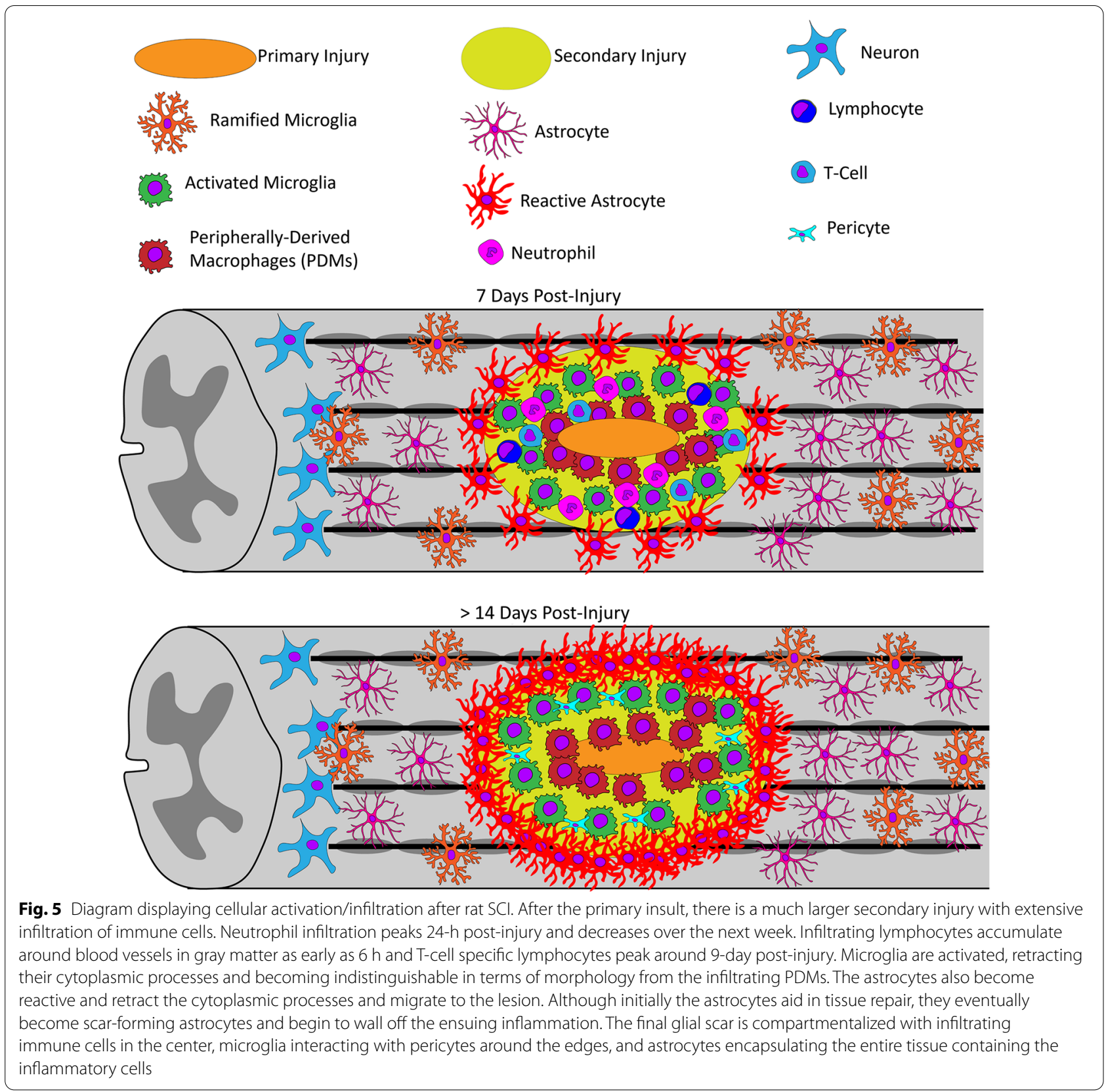

\section{Cytokine signaling and cellular reactions greater than 14-day post-injury}

Astrocytes are the predominant subtype of glial cells in the central nervous system that work to maintain neurons as well as the blood spinal cord barrier [112]. Although initially reactive astrocytes migrate to the lesion and aid in the tissue repair process after SCI, they eventually become scar-forming astrocytes and form a glial scar around the lesion [112]. This thick layer of astrocytes surrounding the injury site is characterized by cellular hypertrophy, process extension, and the increased expression of intermediate filaments, such as glial fibrillary acidic protein (GFAP) (Fig. 5) [112].

T-cells are responsible for cell mediated adaptive immunity [113]. Infiltration of T-cells into the injured spinal cord occurs at different times depending on the species and strain of animal $[110,111]$. After SCI, T-cell proliferation and cytokine production is further induced by chemokines CXCL10 and RANTES [113-116]. It is still a controversial topic on whether T-cells cause secondary degeneration or mediate wound repair after SCI [111, 113, 117, 118]. Gonzalez et al. [119] neutralized 
the chemoattractant CXCL10 and showed that it limited T-cell infiltration and improved tissue preservation and functional recovery, suggesting a negative role for T-cells. After SCI in rats, Wu et al. [120] observed that the dominant T-cells were cytotoxic T-cells (>90\%) with small numbers of regulatory T-cells $(<10 \%)$, which again suggests more of a destructive role in regard to tissue recovery. Furthermore, Lui et al. [121] showed that T-cell-derived perforin destroys the blood spinal cord barrier after SCI, resulting in an infiltration of inflammatory cytokines aggravating secondary injury. After SCI in mice, T-cell infiltration peaks around 14 days, decreases for approximately 2 weeks, then increases again over the next few weeks to reach amounts similar to the level at 14-day post-injury, and are still detected for at least 42-day post-injury [12, 120, 122-125].

After SCI, pericytes, the main source of the scar connective tissue, enter the lesion area with blood vessel sprouts and form the stromal component of the scar tissue [126]. Pericytes can also be activated by trace amines to locally constrict the vasculature [127]. Thus, pericytes regulate the capillary tone and blood flow in the spinal cord after injury. After SCI in mice, the number of pericyte-derived cells peaked at 2 weeks, which was shown to be more than a 25 -fold increase, and then decreased after 4 months before leveling off and remaining for at least 7 months [126]. The final glial scar is compartmentalized with infiltrating immune cells in the center, microglia interacting with pericytes around the edges, and astrocytes surrounding the periphery (Fig. 5) [99, 126].

\section{Conclusions}

Over the past few decades, there have been a plethora of researchers studying the complex inflammatory process that follows SCI. This research has helped to define the critical timeline of cell infiltration and cytokine profiles that occur after SCI. The majority of this work has been performed using rodent models. Although there are many similarities in both rats and mice after SCI, differences exist in terms of neutrophil infiltration, lymphocyte infiltration, fibrotic scarring, and an absence of cysts in mice. Overall, these rodent models have served well in defining the cytokines, chemokines, and reactive species involved after SCI.

To date, there is no successful treatment for SCI patients to either help retain function after the injury, or regain function through regeneration after the injury. Many scientists are in agreement that adapting/minimizing the secondary injury that occurs after SCI would be a premiere target for treating SCI patients. Thus, research needs to continue in this area to discover new mechanisms to modulate inflammation after SCI.

\section{Abbreviations}

4-HNE: 4-Hydroxynonenal; CASP1/ICE: Caspase-1/interleukin-1 converting enzyme; CXCL1: C-X-C Motif Chemokine Ligand 1; CNS: Central nervous system; CSF: Cerebrospinal fluid; COX: Cyclooxygenase; ELISA: Enzyme-linked immunosorbent assay; GFAP: Glial fibrillary acidic protein; GM-CSF: Granulocyte-macrophage colony-stimulating factor; GRO: Growth-related oncogene; IFN- $\gamma$ : Interferon gamma; IL: Interleukin; MCP-1: Monocyte chemoattractant protein 1; MeSH: Medical Subject Headings; MHC: Major histocompatibility complex; MIF: Macrophage migration inhibitory factor; MIP-1a: Macrophage inflammatory protein 1-alpha; NK: Natural killer; PDMs: Peripherally derived macrophages; RANTES: Regulated upon activation, normal T-cell expressed and presumably secreted; RNS: Reactive nitrogen species; ROS: Reactive oxygen species; SCl: Spinal cord injury; TACE/ADAM17: Tumor necrosis factor alpha converting enzyme; TGF- $\beta$ : Transforming growth factor beta; TNFa: Tumor necrosis factor alpha.

\section{Acknowledgements}

Not applicable.

\section{Authors' contributions}

All authors had full access to all the data in the study and take responsibility for the integrity of the data and the accuracy of the data analysis. Literature research was performed by: DJH, CMQ, ZJP. CNM, and JAF. Analysis and interpretation of data: $\mathrm{ASH}, \mathrm{DJH}, \mathrm{CMQ}$, and ZJP. Drafting of the manuscript and critical revision of the article: DJH, CMQ, ZJP and ASH. All authors read and approved the final manuscript.

\section{Funding}

This work was supported by National Institutes of Health under Award Number R56NS117935.

\section{Availability of data and materials}

The data sets used and analyzed during the current study are included within the article and its additional files. All material used in this review are from publicly available articles.

\section{Declarations}

Ethics approval and consent to participate

Not applicable.

\section{Consent for publication}

Not applicable.

\section{Competing interests}

The authors declare that they have no competing interests.

Received: 17 August 2021 Accepted: 30 November 2021

Published online: 07 December 2021

\section{References}

1. Hachem LD, Ahuja CS, Fehlings MG. Assessment and management of acute spinal cord injury: from point of injury to rehabilitation. J Spinal Cord Med. 2017;40:665-75.

2. Fawcett JW, Asher RA. The glial scar and central nervous system repair. Brain Res Bull. 1999;49:377-91.

3. Glaser J, Gonzalez R, Perreau VM, Cotman CW, Keirstead HS. Neutralization of the chemokine $\mathrm{CXCl} 10$ enhances tissue sparing and angiogenesis following spinal cord injury. J Neurosci Res. 2004;77:701-8.

4. Garcia E, Aguilar-Cevallos J, Silva-Garcia R, Ibarra A. Cytokine and growth factor activation in vivo and in vitro after spinal cord injury. Mediat Inflamm. 2016;2016: 9476020.

5. Garcia E, Mondragon-Caso J, Ibarra A. Spinal cord injury: potential neuroprotective therapy based on neural-derived peptides. Neural Regen Res. 2016;11:1762-3.

6. Mortazavi MM, Verma K, Harmon OA, Griessenauer CJ, Adeeb N, Theodore N, Tubbs RS. The microanatomy of spinal cord injury: a review. Clin Anat. 2015;28:27-36. 
7. Lee SI, Jeong SR, Kang YM, Han DH, Jin BK, Namgung U, Kim BG. Endogenous expression of interleukin-4 regulates macrophage activation and confines cavity formation after traumatic spinal cord injury. J Neurosci Res. 2010;88:2409-19.

8. Zhang Z, Krebs CJ, Guth L. Experimental analysis of progressive necrosis after spinal cord trauma in the rat: etiological role of the inflammatory response. Exp Neurol. 1997;143:141-52.

9. Kuhn PL, Wrathall JR. A mouse model of graded contusive spinal cord injury. J Neurotrauma. 1998;15:125-40.

10. Steward O, Schauwecker PE, Guth L, Zhang Z, Fujiki M, Inman D, Wrathall J, Kempermann G, Gage FH, Saatman KE, Raghupathi R, McIntosh T. Genetic approaches to neurotrauma research: opportunities and potential pitfalls of murine models. Exp Neurol. 1999;157:19-42.

11. Jakeman LB, Guan Z, Wei P, Ponnappan R, Dzwonczyk R, Popovich PG, Stokes BT. Traumatic spinal cord injury produced by controlled contusion in mouse. J Neurotrauma. 2000;17:299-319.

12. Kigerl KA, McGaughy VM, Popovich PG. Comparative analysis of lesion development and intraspinal inflammation in four strains of mice following spinal contusion injury. J Comp Neurol. 2006;494:578-94.

13. DiSabato DJ, Quan N, Godbout JP. Neuroinflammation: the devil is in the details. J Neurochem. 2016;139(Suppl 2):136-53.

14. Kwon BK, Stammers AM, Belanger LM, Bernardo A, Chan D, Bishop CM, Slobogean GP, Zhang H, Umedaly H, Giffin M, Street J, Boyd MC, Paquette SJ, Fisher CG, Dvorak MF. Cerebrospinal fluid inflammatory cytokines and biomarkers of injury severity in acute human spinal cord injury. J Neurotrauma. 2010;27:669-82.

15. Ogurcov S, Shulman I, Garanina E, Sabirov D, Baichurina I, Kuznetcov M, Masgutova G, Kostennikov A, Rizvanov A, James V, Mukhamedshina Y. Blood serum cytokines in patients with subacute spinal cord injury: a pilot study to search for biomarkers of injury severity. Brain Sci. 2021;11:322.

16. Kwon BK, Streijger F, Fallah N, Noonan VK, Belanger LM, Ritchie L, Paquette SJ, Ailon T, Boyd MC, Street J, Fisher CG, Dvorak MF. Cerebrospinal fluid biomarkers to stratify injury severity and predict outcome in human traumatic spinal cord injury. J Neurotrauma. 2017;34:567-80.

17. Cox A, Varma A, Barry J, Vertegel A, Banik N. Nanoparticle estrogen in rat spinal cord injury elicits rapid anti-inflammatory effects in plasma, cerebrospinal fluid, and tissue. J Neurotrauma. 2015;32:1413-21.

18. Hasturk A, Atalay B, Calisaneller T, Ozdemir O, Oruckaptan H, Altinors N. Analysis of serum pro-inflammatory cytokine levels after rat spinal cord ischemia/reperfusion injury and correlation with tissue damage. Turk Neurosurg. 2009;19:353-9.

19. Jiang Y, Gong FL, Zhao GB, Li J. Chrysin suppressed inflammatory responses and the inducible nitric oxide synthase pathway after spinal cord injury in rats. Int J Mol Sci. 2014;15:12270-9.

20. Celik H, Karatay M, Erdem Y, Yildirim AE, Sertbas I, Karatay E, Kul H, Guvenc Y, Koksal I, Menekse G, Alagoz F, Kertmen HH, Caydere M. The biochemical, histopathological and clinical comparison of the neuroprotective effects of subcutaneous adalimumab and intravenous methylprednisolone in an experimental compressive spinal cord trauma model. Turk Neurosurg. 2016;26:622-31.

21. Zeng H, Liu N, Yang YY, Xing HY, Liu XX, Li F, La GY, Huang MJ, Zhou MW. Lentivirus-mediated downregulation of alpha-synuclein reduces neuroinflammation and promotes functional recovery in rats with spinal cord injury. J Neuroinflamm. 2019;16:283.

22. Blight AR. Delayed demyelination and macrophage invasion: a candidate for secondary cell damage in spinal cord injury. Cent Nerv Syst Trauma. 1985;2:299-315.

23. Tator $\mathrm{CH}$. Review of experimental spinal cord injury with emphasis on the local and systemic circulatory effects. Neurochirurgie. 1991;37:291-302.

24. Young W. Secondary injury mechanisms in acute spinal cord injury. J Emerg Med. 1993;1 1(Suppl 1):13-22.

25. Kwon BK, TetzlaffW, Grauer JN, Beiner J, Vaccaro AR. Pathophysiology and pharmacologic treatment of acute spinal cord injury. Spine J. 2004:4:451-64.

26. LaPlaca MC, Simon CM, Prado GR, Cullen DK. CNS injury biomechanics and experimental models. Prog Brain Res. 2007;161:13-26.

27. Choo AM, Liu J, Lam CK, Dvorak M, Tetzlaff W, Oxland TR. Contusion, dislocation, and distraction: primary hemorrhage and membrane permeability in distinct mechanisms of spinal cord injury. J Neurosurg Spine. 2007;6:255-66.

28. Oyinbo CA. Secondary injury mechanisms in traumatic spinal cord injury: a nugget of this multiply cascade. Acta Neurobiol Exp. 2011;71:281-99.

29. Schanne FA, Kane AB, Young EE, Farber JL. Calcium dependence of toxic cell death: a final common pathway. Science. 1979;206:700-2.

30. Davalos D, Grutzendler J, Yang G, Kim JV, Zuo Y, Jung S, Littman DR, Dustin ML, Gan WB. ATP mediates rapid microglial response to local brain injury in vivo. Nat Neurosci. 2005;8:752-8.

31. Hines DJ, Hines RM, Mulligan SJ, Macvicar BA. Microglia processes block the spread of damage in the brain and require functional chloride channels. Glia. 2009;57:1610-8.

32. Popovich PG, Guan Z, McGaughy V, Fisher L, Hickey WF, Basso DM. The neuropathological and behavioral consequences of intraspinal microglial/macrophage activation. J Neuropathol Exp Neurol. 2002;61:623-33.

33. David S, Kroner A. Repertoire of microglial and macrophage responses after spinal cord injury. Nat Rev Neurosci. 2011;12:388-99.

34. David S, Lopez-Vales R, Wee YV. Harmful and beneficial effects of inflammation after spinal cord injury: potential therapeutic implications. Handb Clin Neurol. 2012;109:485-502.

35. Popovich P, McTigue D. Damage control in the nervous system: beware the immune system in spinal cord injury. Nat Med. 2009;15:736-7.

36. Kroner A, Greenhalgh AD, Zarruk JG, Passos Dos Santos, Gaestel M, David S. TNF and increased intracellular iron alter macrophage polarization to a detrimental M1 phenotype in the injured spinal cord. Neuron. 2014;83:1098-116.

37. Pineau I, Lacroix S. Proinflammatory cytokine synthesis in the injured mouse spinal cord: multiphasic expression pattern and identification of the cell types involved. J Comp Neurol. 2007:500:267-85.

38. Stammers AT, Liu J, Kwon BK. Expression of inflammatory cytokines following acute spinal cord injury in a rodent model. J Neurosci Res. 2012;90:782-90.

39. Bethea JR, Nagashima H, Acosta MC, Briceno C, Gomez F, Marcillo AE, Loor K, Green J, Dietrich WD. Systemically administered interleukin-10 reduces tumor necrosis factor-alpha production and significantly improves functional recovery following traumatic spinal cord injury in rats. J Neurotrauma. 1999;16:851-63.

40. Pan JZ, Ni L, Sodhi A, Aguanno A, Young W, Hart RP. Cytokine activity contributes to induction of inflammatory cytokine mRNAs in spinal cord following contusion. J Neurosci Res. 2002;68:315-22.

41. Streit WJ, Semple-Rowland SL, Hurley SD, Miller RC, Popovich PG, Stokes BT. Cytokine mRNA profiles in contused spinal cord and axotomized facial nucleus suggest a beneficial role for inflammation and gliosis. Exp Neurol. 1998;152:74-87.

42. Wang J, Chen J, Jin H, Lin D, Chen Y, Chen X, Wang B, Hu S, Wu Y, Wu Y, Zhou Y, Tian N, Gao W, Wang X, Zhang X. BRD4 inhibition attenuates inflammatory response in microglia and facilitates recovery after spinal cord injury in rats. J Cell Mol Med. 2019;23:3214-23.

43. Hasturk AE, Yilmaz ER, Turkoglu E, Arikan M, Togral G, Hayirli N, Erguder $\mathrm{BI}$, Evirgen O. Potential neuroprotective effect of anakinra in spinal cord injury in an in vivo experimental animal model. Neurosciences. 2015;20:124-30.

44. Martinon S, Ibarra A. Pharmacological neuroprotective therapy for acute spinal cord injury: state of the art. Mini Rev Med Chem. 2008;8:222-30.

45. Hall JC, Priestley JV, Perry VH, Michael-Titus AT. Docosahexaenoic acid, but not eicosapentaenoic acid, reduces the early inflammatory response following compression spinal cord injury in the rat. J Neurochem. 2012;121:738-50.

46. Tai PA, Chang CK, Niu KC, Lin MT, Chiu WT, Lin CM. Attenuating experimental spinal cord injury by hyperbaric oxygen: stimulating production of vasculoendothelial and glial cell line-derived neurotrophic growth factors and interleukin-10. J Neurotrauma. 2010;27:1121-7.

47. Sanchez-Ventura J, Amo-Aparicio J, Navarro X, Penas C. BET protein inhibition regulates cytokine production and promotes neuroprotection after spinal cord injury. J Neuroinflamm. 2019;16:124.

48. Bao C, Wang B, Yang F, Chen L. Blockade of interleukin-7 receptor shapes macrophage alternative activation and promotes functional recovery after spinal cord injury. Neuroscience. 2018;371:518-27. 
49. McTigue DM, Tani M, Krivacic K, Chernosky A, Kelner GS, Maciejewski D, Maki R, Ransohoff RM, Stokes BT. Selective chemokine mRNA accumulation in the rat spinal cord after contusion injury. J Neurosci Res. 1998;53:368-76.

50. Tonai T, Shiba K, Taketani Y, Ohmoto Y, Murata K, Muraguchi M, Ohsak $H$, Takeda E, Nishisho T. A neutrophil elastase inhibitor (ONO-5046) reduces neurologic damage after spinal cord injury in rats. J Neurochem. 2001;78:1064-72

51. Zhou Y, Guo W, Zhu Z, Hu Y, Wang Y, Zhang X, Wang W, Du N, Song T, Yang K, Guan Z, Wang Y, Guo A. Macrophage migration inhibitory factor facilitates production of $\mathrm{CCl} 5$ in astrocytes following rat spinal cord injuRY. J Neuroinflamm. 2018;15:253.

52. Hellenbrand DJ, Roddick RM, Mauney SM, Elder RT, Morehouse CN, Hanna AS. The role of interleukins after spinal cord injury. In: Behzadi $P$, editor. Interleukins: the immune and non-immune systems' related cytokines. London: IntechOpen; 2021.

53. Junttila IS. Tuning the cytokine responses: an update on interleukin (IL)-4 and IL-13 receptor complexes. Front Immunol. 2018;9:888.

54. Gordon S, Martinez FO. Alternative activation of macrophages: mechanism and functions. Immunity. 2010;32:593-604.

55. McCormick SM, Heller NM. Commentary: IL-4 and IL-13 receptors and signaling. Cytokine. 2015;75:38-50.

56. Thompson CD, Zurko JC, Hanna BF, Hellenbrand DJ, Hanna A. The therapeutic role of interleukin-10 after spinal cord injury. J Neurotrauma. 2013;30:1311-24.

57. Hellenbrand DJ, Reichl KA, Travis BJ, Filipp ME, Khalil AS, Pulito DJ, Gavigan AV, Maginot ER, Arnold MT, Adler AG, Murphy WL, Hanna AS. Sustained interleukin-10 delivery reduces inflammation and improves motor function after spinal cord injury. J Neuroinflammation. 2019;16:93.

58. Fritz RB, Skeen MJ, Chou CH, Garcia M, Egorov IK. Major histocompatibility complex-linked control of the murine immune response to myelin basic protein. J Immunol. 1985;134:2328-32.

59. Mendel I, Kerlerode Rosbo N, Ben-Nun A. A myelin oligodendrocyte glycoprotein peptide induces typical chronic experimental autoimmune encephalomyelitis in $\mathrm{H}-2^{\mathrm{b}}$ mice: fine specificity and $\mathrm{T}$ cell receptor $\vee$ beta expression of encephalitogenic T cells. Eur J Immunol. 1995;25:1951-9.

60. Tuohy VK, Sobel RA, Lees MB. Myelin proteolipid protein-induced experimental allergic encephalomyelitis. variations of disease expression in different strains of mice. J Immunol. 1988;140:1868-73.

61. Taoka Y, Okajima K, Uchiba M, Murakami K, Kushimoto S, Johno M, Naruo M, Okabe H, Takatsuki K. Role of neutrophils in spinal cord injury in the rat. Neuroscience. 1997;79:1177-82.

62. Carlson SL, Parrish ME, Springer JE, Doty K, Dossett L. Acute inflammatory response in spinal cord following impact injury. Exp Neurol. 1998;151:77-88.

63. Gensel JC, Zhang B. Macrophage activation and its role in repair and pathology after spinal cord injury. Brain Res. 2015;1619:1-11.

64. Nigam S, Schewe T. Phospholipase A(2)s and lipid peroxidation. Biochim Biophys Acta. 2000;1488:167-81.

65. Xiong Y, Rabchevsky AG, Hall ED. Role of peroxynitrite in secondary oxidative damage after spinal cord injury. J Neurochem. 2007;100:639-49.

66. Sandrow-Feinberg HR, Zhukareva V, Santi L, Miller K, Shumsky JS, Baker DP, Houle JD. Pegylated interferon-beta modulates the acute inflammatory response and recovery when combined with forced exercise following cervical spinal contusion injury. Exp Neurol. 2010;223:439-51.

67. van Neerven S, Mey J, Joosten EA, Steinbusch HW, van Kleef M, Marcus MA, Deumens R. Systemic but not local administration of retinoic acid reduces early transcript levels of pro-inflammatory cytokines after experimental spinal cord injury. Neurosci Lett. 2010;485:21-5.

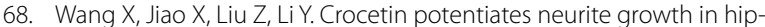
pocampal neurons and facilitates functional recovery in rats with spinal cord injury. Neurosci Bull. 2017;33:695-702.

69. Marsh DR, Flemming JM. Inhibition of CXCR1 and CXCR2 chemokine receptors attenuates acute inflammation, preserves gray matter and diminishes autonomic dysreflexia after spinal cord injury. Spinal Cord. 2011:49:337-44.

70. Francos-Quijorna I, Amo-Aparicio J, Martinez-Muriana A, Lopez-Vales R. IL-4 drives microglia and macrophages toward a phenotype conducive for tissue repair and functional recovery after spinal cord injury. Glia. 2016;64:2079-92.

71. Lu J, Ashwell KW, Waite P. Advances in secondary spinal cord injury: role of apoptosis. Spine. 2000;25:1859-66.

72. Liu XZ, Xu XM, Hu R, Du C, Zhang SX, McDonald JW, Dong HX, Wu YJ, Fan GS, Jacquin MF, Hsu CY, Choi DW. Neuronal and glial apoptosis after traumatic spinal cord injury. J Neurosci. 1997:17:5395-406.

73. Stirling DP, Yong WW. Dynamics of the inflammatory response after murine spinal cord injury revealed by flow cytometry. J Neurosci Res. 2008;86:1944-58

74. Bethea JR, Dietrich WD. Targeting the host inflammatory response in traumatic spinal cord injury. Curr Opin Neurol. 2002;15:355-60.

75. Popovich PG, van Rooijen N, Hickey WF, Preidis G, McGaughy V. Hematogenous macrophages express CD8 and distribute to regions of lesion cavitation after spinal cord injury. Exp Neurol. 2003;182:275-87.

76. Kigerl KA, Gensel JC, Ankeny DP, Alexander JK, Donnelly DJ, Popovich PG. Identification of two distinct macrophage subsets with divergent effects causing either neurotoxicity or regeneration in the injured mouse spinal cord. J Neurosci. 2009;29:13435-44.

77. Shechter R, Schwartz M. Cns sterile injury: just another wound healing? Trends Mol Med. 2013;19:135-43.

78. Ren Y, Young W. Managing inflammation after spinal cord injury through manipulation of macrophage function. Neural Plast. 2013;2013: 945034.

79. Shin T, Ahn M, Moon C, Kim S, Sim KB. Alternatively activated macrophages in spinal cord injury and remission: another mechanism for repair? Mol Neurobiol. 2013:47:1011-9.

80. Thawer SG, Mawhinney L, Chadwick K, de Chickera SN, Weaver LC, Brown A, Dekaban GA. Temporal changes in monocyte and macrophage subsets and microglial macrophages following spinal cord injury in the Lys-Egfp-Ki mouse model. J Neuroimmunol. 2013;261:7-20

81. Stables MJ, Shah S, Camon EB, Lovering RC, Newson J, Bystrom J, Farrow S, Gilroy DW. Transcriptomic analyses of murine resolution-phase macrophages. Blood. 2011;118:e192-208.

82. Li Y, Dalli J, Chiang N, Baron RM, Quintana C, Serhan CN. Plasticity of leukocytic exudates in resolving acute inflammation is regulated by microrna and proresolving mediators. Immunity. 2013;39:885-98.

83. Schwab JM, Chiang N, Arita M, Serhan CN. Resolvin E1 and protectin D1 activate inflammation-resolution programmes. Nature. 2007;447:869-74.

84. Austin JW, Afshar M, Fehlings MG. The relationship between localized subarachnoid inflammation and parenchymal pathophysiology after spinal cord injury. J Neurotrauma. 2012;29:1838-49.

85. Cheng P, Kuang F, Zhang H, Ju G, Wang J. Beneficial effects of thymosin beta4 on spinal cord injury in the rat. Neuropharmacology. 2014;85:408-16.

86. Neirinckx V, Coste C, Franzen R, Gothot A, Rogister B, Wislet S. Neutrophil contribution to spinal cord injury and repair. J Neuroinflamm. 2014;11:150.

87. Mukhamedshina YO, Akhmetzyanova ER, Martynova EV, Khaiboullina SF, Galieva LR, Rizvanov AA. Systemic and local cytokine profile following spinal cord injury in rats: a multiplex analysis. Front Neurol. 2017:8:581.

88. Ellman DG, Degn M, Lund MC, Clausen BH, Novrup HG, Flaeng SB, Jorgensen LH, Suntharalingam L, Svenningsen AF, Brambilla R, Lambertsen KL. Genetic ablation of soluble TNF does not affect lesion size and functional recovery after moderate spinal cord injury in mice. Mediat Inflamm. 2016:2016:2684098.

89. Ellman DG, Lund MC, Nissen M, Nielsen PS, Sorensen C, Lester EB, Thougaard E, Jorgensen LH, Nedospasov SA, Andersen DC, Stubbe J, Brambilla R, Degn M, Lambertsen KL. Conditional ablation of myeloid tnf improves functional outcome and decreases lesion size after spinal cord injury in mice. Cells. 2020;9:2407.

90. Yu WR, Fehlings MG. Fas/Fasl-mediated apoptosis and inflammation are key features of acute human spinal cord injury: implications for translational, clinical application. Acta Neuropathol. 2011;122:747-61.

91. Bartholdi D, Schwab ME. Expression of pro-inflammatory cytokine and chemokine mRNA upon experimental spinal cord injury in mouse: an in situ hybridization study. Eur J Neurosci. 1997;9:1422-38.

92. Ma M, Wei T, Boring L, Charo IF, Ransohoff RM, Jakeman LB. Monocyte recruitment and myelin removal are delayed following spinal cord 
injury in mice with CCR2 chemokine receptor deletion. J Neurosci Res. 2002;68:691-702.

93. Kerr BJ, Girolami El, Ghasemlou N, Jeong SY, David S. The protective effects of 15-deoxy-delta-(12,14)-prostaglandin J2 in spinal cord injury. Glia. 2008:56:436-48.

94. Zhang Y, Zhou Y, Chen S, Hu Y, Zhu Z, Wang Y, Du N, Song T, Yang Y, Guo A, Wang Y. Macrophage migration inhibitory factor facilitates prostaglandin E2 production of astrocytes to tune inflammatory milieu following spinal cord injury. J Neuroinflamm. 2019;16:85.

95. Sun G, Yang S, Cao G, Wang Q, Hao J, Wen Q, Li Z, So KF, Liu Z, Zhou S, Zhao Y, Yang H, Zhou L, Yin Z. Gammadelta T cells provide the early source of IFN-gamma to aggravate lesions in spinal cord injury. J Exp Med. 2018;215:521-35.

96. Martini AC, Berta T, Forner S, Chen G, Bento AF, Ji RR, Rae GA. Lipoxin A4 inhibits microglial activation and reduces neuroinflammation and neuropathic pain after spinal cord hemisection. J Neuroinflamm. 2016;13:75

97. Beck KD, Nguyen HX, Galvan MD, Salazar DL, WoodruffTM, Anderson AJ. Quantitative analysis of cellular inflammation after traumatic spinal cord injury: evidence for a multiphasic inflammatory response in the acute to chronic environment. Brain. 2010;133:433-47.

98. Popovich PG, Wei P, Stokes BT. Cellular inflammatory response after spinal cord injury in Sprague-Dawley and lewis rats. J Comp Neurol. 1997:377:443-64.

99. Bellver-Landete V, Bretheau F, Mailhot B, Vallieres N, Lessard M, Janelle ME, Vernoux N, Tremblay ME, Fuehrmann T, Shoichet MS, Lacroix S. Microglia are an essential component of the neuroprotective scar that forms after spinal cord injury. Nat Commun. 2019;10:518.

100. Horn KP, Busch SA, Hawthorne AL, van Rooijen N, Silver J. Another barrier to regeneration in the CNS: activated macrophages induce extensive retraction of dystrophic axons through direct physical interactions. J Neurosci. 2008;28:9330-41.

101. Busch SA, Horn KP, Silver DJ, Silver J. Overcoming macrophage-mediated axonal dieback following CNS injury. J Neurosci. 2009;29:9967-76.

102. Busch SA, Horn KP, Cuascut FX, Hawthorne AL, Bai L, Miller RH, Silver J. Adult NG2+ cells are permissive to neurite outgrowth and stabilize sensory axons during macrophage-induced axonal dieback after spinal cord injury. J Neurosci. 2010;30:255-65.

103. Busch SA, Hamilton JA, Horn KP, Cuascut FX, Cutrone R, Lehman N, Deans RJ, Ting AE, Mays RW, Silver J. Multipotent adult progenitor cells prevent macrophage-mediated axonal dieback and promote regrowth after spinal cord injury. J Neurosci. 2011:31:944-53.

104. Evans TA, Barkauskas DS, Myers JT, Hare EG, You JQ, Ransohoff RM, Huang AY, Silver J. High-resolution intravital imaging reveals that blood-derived macrophages but not resident microglia facilitate secondary axonal dieback in traumatic spinal cord injury. Exp Neurol. 2014;254:109-20.

105. Bisicchia E, Latini L, Cavallucci V, Sasso V, Nicolin V, Molinari M, D’Amelio M, Viscomi MT. Autophagy inhibition favors survival of rubrospinal neurons after spinal cord hemisection. Mol Neurobiol. 2017;54:4896-907.

106. Perrin FE, Lacroix S, Aviles-Trigueros M, David S. Involvement of monocyte chemoattractant protein-1, macrophage inflammatory protein-1 alpha and interleukin-1 beta in Wallerian degeneration. Brain. 2005;128:854-66.

107. Liu G, Fan G, Guo G, Kang W, Wang D, Xu B, Zhao J. FK506 attenuates the inflammation in rat spinal cord injury by inhibiting the activation of NF-kappaB in microglia cells. Cell Mol Neurobiol. 2017;37:843-55.

108. Tripathi R, McTigue DM. Prominent oligodendrocyte genesis along the border of spinal contusion lesions. Glia. 2007;55:698-711.

109. MCTigue DM, Tripathi RB. The life, death, and replacement of oligodendrocytes in the adult CNS. J Neurochem. 2008;107:1-19.

110. Sroga JM, Jones TB, Kigerl KA, McGaughy VM, Popovich PG. Rats and mice exhibit distinct inflammatory reactions after spinal cord injury. J Comp Neurol. 2003:462:223-40.

111. Fleming JC, Norenberg MD, Ramsay DA, Dekaban GA, Marcillo AE, Saenz AD, Pasquale-Styles M, Dietrich WD, Weaver LC. The cellular inflammatory response in human spinal cords after injury. Brain. 2006;129:3249-69.

112. Okada S, Hara M, Kobayakawa K, Matsumoto Y, Nakashima Y. Astrocyte reactivity and astrogliosis after spinal cord injury. Neurosci Res. 2018:126:39-43.
113. Jones TB, Hart RP, Popovich PG. Molecular control of physiological and pathological T-cell recruitment after mouse spinal cord injury. J Neurosci. 2005;25:6576-83.

114. Bacon KB, Premack BA, Gardner P, Schall TJ. Activation of dual T cell signaling pathways by the chemokine RANTES. Science. 1995;269:1727-30.

115. Appay V, Dunbar PR, Cerundolo V, McMichael A, Czaplewski L, RowlandJones $\mathrm{S}$. Rantes activates antigen-specific cytotoxic T lymphocytes in a mitogen-like manner through cell surface aggregation. Int Immunol. 2000:12:1173-82.

116. Dufour JH, Dziejman M, Liu MT, Leung JH, Lane TE, Luster AD. IFNgamma-inducible protein 10 (IP-10; CXCL10)-deficient mice reveal a role for IP-10 in effector T cell generation and trafficking. J Immunol. 2002:168:3195-204.

117. Hauben E, Gothilf A, Cohen A, Butovsky O, Nevo U, Smirnov I, Yoles E, Akselrod S, Schwartz M. Vaccination with dendritic cells pulsed with peptides of myelin basic protein promotes functional recovery from spinal cord injury. J Neurosci. 2003;23:8808-19.

118. Crutcher KA, Gendelman HE, Kipnis J, Perez-Polo JR, Perry VH, Popovich $P G$, Weaver LC. Debate: "Is increasing neuroinflammation beneficial for neural repair?" J Neuroimmune Pharmacol. 2006;1:195-211.

119. Gonzalez R, Glaser J, Liu MT, Lane TE, Keirstead HS. Reducing inflammation decreases secondary degeneration and functional deficit after spinal cord injury. Exp Neurol. 2003;184:456-63.

120. Wu Y, Lin YH, Shi LL, Yao ZF, Xie XM, Jiang ZS, Tang J, Hu JG, Lu HZ. Temporal kinetics of CD8(+) CD28(+) and CD8(+) CD28(-) T lymphocytes in the injured rat spinal cord. J Neurosci Res. 2017;95:1666-76.

121. Liu Z, Zhang H, Xia H, Wang B, Zhang R, Zeng Q, Guo L, Shen K, Wang B, Zhong Y, Li Z, Sun G. CD8 T cell-derived perforin aggravates secondary spinal cord injury through destroying the blood-spinal cord barrier. Biochem Biophys Res Commun. 2019;512:367-72.

122. Bowes AL, Yip PK. Modulating inflammatory cell responses to spinal cord injury: all in good time. J Neurotrauma. 2014;31:1753-66.

123. David S, Greenhalgh AD, Kroner A. Macrophage and microglial plasticity in the injured spinal cord. Neuroscience. 2015;307:311-8.

124. Donnelly DJ, Popovich PG. Inflammation and its role in neuroprotection, axonal regeneration and functional recovery after spinal cord injury. Exp Neurol. 2008;209:378-88.

125. Gadani SP, Walsh JT, Lukens JR, Kipnis J. Dealing with danger in the CNS: the response of the immune system to injury. Neuron. 2015;87:47-62.

126. Goritz C, Dias DO, Tomilin N, Barbacid M, Shupliakov O, Frisen J. A pericyte origin of spinal cord scar tissue. Science. 2011;333:238-42.

127. Picoli CC, Coimbra-Campos LMC, Guerra DAP, Silva WN, Prazeres PH, Costa AC, Magno LAV, Romano-Silva MA, Mintz A, Birbrair A. Pericytes act as key players in spinal cord injury. Am J Pathol. 2019;189:1327-37.

128. Bastien D, Bellver LV, Lessard M, Vallieres N, Champagne M, Takashima A, Tremblay ME, Doyon Y, Lacroix S. IL-1alpha gene deletion protects oligodendrocytes after spinal cord injury through upregulation of the survival factor Tox3. J Neurosci. 2015;35:10715-30.

129. Wang XF, Huang LD, Yu PP, Hu JG, Yin L, Wang L, Xu XM, Lu PH. Upregulation of type I interleukin-1 receptor after traumatic spinal cord injury in adult rats. Acta Neuropathol. 2006:111:220-8.

130. Mariathasan S, Newton K, Monack DM, Vucic D, French DM, Lee WP, Roose-Girma M, Erickson S, Dixit VM. Differential activation of the inflammasome by caspase-1 adaptors ASC and Ipaf. Nature. 2004:430:213-8.

131. Liu Z, Yao X, Jiang W, Li W, Zhu S, Liao C, Zou L, Ding R, Chen J. Advanced oxidation protein products induce microglia-mediated neuroinflammation via MAPKs-NF-kappaB signaling pathway and pyroptosis after secondary spinal cord injury. J Neuroinflamm. 2020;17:90.

132. Liu S, Xu GY, Johnson KM, Echetebu C, Ye ZS, Hulsebosch CE, McAdoo DJ. Regulation of interleukin-1 beta by the interleukin-1 receptor antagonist in the glutamate-injured spinal cord: endogenous neuroprotection. Brain Res. 2008;1231:63-74.

133. Tonai T, Taketani Y, Ueda N, Nishisho T, Ohmoto Y, Sakata Y, Muraguchi M, Wada K, Yamamoto S. Possible involvement of interleukin-1 in cyclooxygenase-2 induction after spinal cord injury in rats. J Neurochem. 1999;72:302-9.

134. Nelson BH. II-2, regulatory T cells, and tolerance. J Immunol. 2004;172:3983-8 
135. Waldmann TA. The shared and contrasting roles of IL2 and IL15 in the life and death of normal and neoplastic lymphocytes: implications for cancer therapy. Cancer Immunol Res. 2015;3:219-27.

136. Gadani SP, Cronk JC, Norris GT, Kipnis J. IL-4 in the brain: a cytokine to remember. J Immunol. 2012;189:4213-9.

137. Lima R, Monteiro S, Lopes JP, Barradas P, Vasconcelos NL, Gomes ED, Assuncao-Silva RC, Teixeira FG, Morais M, Sousa N, Salgado AJ, Silva NA. Systemic interleukin-4 administration after spinal cord injury modulates inflammation and promotes neuroprotection. Pharmaceuticals. 2017;10:83.

138. Takatsu K. Interleukin-5 and IL-5 receptor in health and diseases. Proc Jpn Acad Ser B Phys Biol Sci. 2011;87:463-85.

139. Shi LL, Zhang N, Xie XM, Chen YJ, Wang R, Shen L, Zhou JS, Hu JG, Lu $\mathrm{HZ}$. Transcriptome profile of rat genes in injured spinal cord at different stages by RNA-sequencing. BMC Genom. 2017;18:173.

140. van Leeuwen BH, Martinson ME, Webb GC, Young IG. Molecular organization of the cytokine gene cluster, involving the human IL-3, IL-4, IL-5, and GM-CSF genes, on human chromosome 5. Blood. 1989;73:1142-8.

141. Rose-John S. Interleukin-6 family cytokines. Cold Spring Harb Perspect Biol. 2018;10: a028415.

142. Lacroix S, Chang L, Rose-John S, Tuszynski MH. Delivery of hyperinterleukin- 6 to the injured spinal cord increases neutrophil and macrophage infiltration and inhibits axonal growth. J Comp Neurol. 2002;454:213-28.

143. Bonni A, Sun Y, Nadal-Vicens M, Bhatt A, Frank DA, Rozovsky I, Stahl $N$, Yancopoulos GD, Greenberg ME. Regulation of gliogenesis in the central nervous system by the JAK-STAT signaling pathway. Science. 1997;278:477-83.

144. Russo RC, Garcia CC, Teixeira MM, Amaral FA. The CXCL8/IL-8 chemokine family and its receptors in inflammatory diseases. Expert Rev Clin Immunol. 2014;10:593-619.

145. Couper KN, Blount DG, Riley EM. IL-10: the master regulator of immunity to infection. J Immunol. 2008;180:5771-7.

146. Shouval DS, Ouahed J, Biswas A, Goettel JA, Horwitz BH, Klein C, Muise AM, Snapper SB. Interleukin 10 receptor signaling: master regulator of intestinal mucosal homeostasis in mice and humans. Adv Immunol. 2014;122:177-210.

147. Liu J, Cao S, Kim S, Chung EY, Homma Y, Guan X, Jimenez V, Ma X. Interleukin-12: an update on its immunological activities, signaling and regulation of gene expression. Curr Immunol Rev. 2005;1:119-37.

148. Hamza T, Barnett JB, Li B. Interleukin 12 a key immunoregulatory cytokine in infection applications. Int J Mol Sci. 2010;11:789-806.

149. Jana M, Pahan K. IL-12 p40 homodimer, but not IL-12 p70, induces the expression of IL-16 in microglia and macrophages. Mol Immunol. 2009;46:773-83.

150. de Vries JE. The role of IL-13 and its receptor in allergy and inflammatory responses. J Allergy Clin Immunol. 1998;102:165-9.

151. Fichtner-Feigl S, Strober W, Kawakami K, Puri RK, Kitani A. IL-13 signaling through the IL-13a2 receptor is involved in induction of TGF- $\beta 1$ production and fibrosis. Nat Med. 2006;12:99-106

152. Onishi RM, Gaffen SL. Interleukin-17 and its target genes: mechanisms of interleukin-17 function in disease. Immunology. 2010;129:311-21.

153. Hill F, Kim CF, Gorrie CA, Moalem-Taylor G. Interleukin-17 deficiency improves locomotor recovery and tissue sparing after spinal cord contusion injury in mice. Neurosci Lett. 2011:487:363-7.

154. Probert L. TNF and its receptors in the CNS: the essential, the desirable and the deleterious effects. Neuroscience. 2015:302:2-22.

155. Ishii H, Tanabe S, Ueno M, Kubo T, Kayama H, Serada S, Fujimoto M, Takeda K, Naka T, Yamashita T. IFN-gamma-dependent secretion of IL-10 from Th1 cells and microglia/macrophages contributes to functional recovery after spinal cord injury. Cell Death Dis. 2013;4:e710.

156. Zhang X, He B, Li H, Wang Y, Zhou Y, Wang W, Song T, Du N, Gu X, Luo Y, Wang Y. SOCS3 attenuates GM-CSF/IFN-gamma-mediated inflammation during spontaneous spinal cord regeneration. Neurosci Bull. 2020;36:778-92

157. Shi Y, Liu CH, Roberts Al, Das J, Xu G, Ren G, Zhang Y, Zhang L, Yuan ZR, Tan HS, Das G, Devadas S. Granulocyte-macrophage colony-stimulating factor (GM-CSF) and T-cell responses: what we do and don't know. Cell Res. 2006;16:126-33.
158. Hayashi K, Ohta S, Kawakami Y, Toda M. Activation of dendritic-like cells and neural stem/progenitor cells in injured spinal cord by GM-CSF. Neurosci Res. 2009;64:96-103.

159. Huang $X$, Kim JM, Kong TH, Park SR, Ha Y, Kim MH, Park H, Yoon SH, Park HC, Park JO, Min BH, Choi BH. GM-CSF inhibits glial scar formation and shows long-term protective effect after spinal cord injury. J Neurol Sci. 2009;277:87-97.

160. Huang X, Choi JK, Park SR, Ha Y, Park H, Yoon SH, Park HC, Park JO, Choi $\mathrm{BH}$. GM-CSF inhibits apoptosis of neural cells via regulating the expression of apoptosis-related proteins. Neurosci Res. 2007;58:50-7.

161. Ousman SS, David S. MIP-1alpha, MCP-1, GM-CSF, and TNF-alpha control the immune cell response that mediates rapid phagocytosis of myelin from the adult mouse spinal cord. J Neurosci. 2001;21:4649-56.

162. Wang Y, Li C, Gao C, Li Z, Yang J, Liu X, Liang F. Effects of hyperbaric oxygen therapy on rage and MCP-1 expression in rats with spinal cord injury. Mol Med Rep. 2016;14:5619-25.

163. Pelisch N, Rosas AJ, Stehlik KE, Aperi BV, Kroner A. CCl3 contributes to secondary damage after spinal cord injury. J Neuroinflamm. 2020;17:362.

164. Yagura K, Ohtaki H, Tsumuraya T, Sato A, Miyamoto K, Kawada N, Suzuki K, Nakamura M, Kanzaki K, Dohi K, Izumizaki M, Hiraizumi Y, Honda K. The enhancement of $\mathrm{CCl} 2$ and $\mathrm{CCl} 5$ by human bone marrow-derived mesenchymal stem/stromal cells might contribute to inflammatory suppression and axonal extension after spinal cord injury. PLOS ONE. 2020;15: e0230080.

165. Lin MS, Sun YY, Chiu WT, Hung CC, Chang CY, Shie FS, Tsai SH, Lin JW, Hung KS, Lee $\mathrm{YH}$. Curcumin attenuates the expression and secretion of rantes after spinal cord injury in vivo and lipopolysaccharide-induced astrocyte reactivation in vitro. J Neurotrauma. 2011;28:1259-69.

166. Letterio JJ, Roberts AB. Regulation of immune responses by TGF-beta. Annu Rev Immunol. 1998;16:137-61.

167. Vander AA, Cao J, Li X. TGF-beta receptors: in and beyond TGF-beta signaling. Cell Signal. 2018;52:112-20.

168. Liu R, Wang W, Wang S, Xie W, Li H, Ning B. Microrna-21 regulates astrocytic reaction post-acute phase of spinal cord injury through modulating TGF-beta signaling. Aging. 2018;10:1474-88.

169. Kadota R, Koda M, Kawabe J, Hashimoto M, Nishio Y, Mannoji C, Miyashita T, Furuya T, Okawa A, Takahashi K, Yamazaki M. Granulocyte colony-stimulating factor (G-CSF) protects oligodendrocyte and promotes hindlimb functional recovery after spinal cord injury in rats. PLoS ONE. 2012;7: e50391.

170. Genovese T, Esposito E, Mazzon E, Di Paola R, Caminiti R, Bramanti P, Cappelani A, Cuzzocrea S. Absence of endogenous interleukin-10 enhances secondary inflammatory process after spinal cord compression injury in mice. J Neurochem. 2009;108:1360-72.

171. Genovese T, Esposito E, Mazzon E, Di Paola R, Meli R, Bramanti P, Piomelli D, Calignano A, Cuzzocrea S. Effects of palmitoylethanolamide on signaling pathways implicated in the development of spinal cord injury. J Pharmacol Exp Ther. 2008;326:12-23.

172. Li Z, Wu F, Xu D, Zhi Z, Xu G. Inhibition of trem 1 reduces inflammation and oxidative stress after spinal cord injury $(\mathrm{SCl})$ associated with $\mathrm{HO}-1$ expressions. Biomed Pharmacother. 2019;109:2014-21.

173. Ko WK, Kim SJ, Jo MJ, Choi H, Lee D, Kwon IK, Lee SH, Han IB, Sohn S. Ursodeoxycholic acid inhibits inflammatory responses and promotes functional recovery after spinal cord injury in rats. Mol Neurobiol. 2019;56:267-77.

174. Sabirzhanov B, Li Y, Coll-Miro M, Matyas JJ, He J, Kumar A, Ward N Yu J, Faden Al, Wu J. Inhibition of NOX2 signaling limits pain-related behavior and improves motor function in male mice after spinal cord injury: participation of IL-10/miR-155 pathways. Brain Behav Immun. 2019:80:73-87.

175. Yan X, Huang G, Liu Q, Zheng J, Chen H, Huang Q, Chen J, Huang H. Withaferin a protects against spinal cord injury by inhibiting apoptosis and inflammation in mice. Pharm Biol. 2017;55:1171-6.

176. Truflandier K, Beaumont E, Charbonney E, Maghni K, de Marchie M, Spahija J. Mechanical ventilation modulates pro-inflammatory cytokine expression in spinal cord tissue after injury in rats. Neurosci Lett. 2018:671:13-8.

177. Paterniti I, Impellizzeri D, Crupi R, Morabito R, Campolo M, Esposito E, Cuzzocrea S. Molecular evidence for the involvement of PPAR-delta and PPAR-gamma in anti-inflammatory and neuroprotective activities 
of palmitoylethanolamide after spinal cord trauma. J Neuroinflamm. 2013;10:20.

178. Pomeshchik Y, Kidin I, Korhonen P, Savchenko E, Jaronen M, Lehtonen S, Wojciechowski S, Kanninen K, Koistinaho J, Malm T. Interleukin-33 treatment reduces secondary injury and improves functional recovery after contusion spinal cord injury. Brain Behav Immun. 2015;44:68-81.

179. Sun C, Li B, Duan H, Tao B, Zhao C, Li W, Pang Y, Fan B, Feng S. Cytokine expressions of spinal cord injury treated by neurotropin and nafamostat mesylate. Ann Transl Med. 2021;9:489.

180. Cantarella G, Di Benedetto G, Scollo M, Paterniti I, Cuzzocrea S, Bosco P, Nocentini G, Riccardi C, Bernardini R. Neutralization of tumor necrosis factor-related apoptosis-inducing ligand reduces spinal cord injury damage in mice. Neuropsychopharmacology. 2010;35:1302-14.

181. Church JS, Kigerl KA, Lerch JK, Popovich PG, McTigue DM. TLR4 deficiency impairs oligodendrocyte formation in the injured spinal cord. J Neurosci. 2016;36:6352-64.

182. Esposito E, Rinaldi B, Mazzon E, Donniacuo M, Impellizzeri D, Paterniti I, Capuano A, Bramanti P, Cuzzocrea S. Anti-inflammatory effect of simvastatin in an experimental model of spinal cord trauma: involvement of PPAR-alpha. J Neuroinflamm. 2012;9:81.

183. Gorio A, Madaschi L, Di Stefano B, Carelli S, Di Giulio AM, De Biasi S, Coleman T, Cerami A, Brines M. Methylprednisolone neutralizes the beneficial effects of erythropoietin in experimental spinal cord injury. Proc Natl Acad Sci USA. 2005;102:16379-84.

184. Gorio A, Madaschi L, Zadra G, Marfia G, Cavalieri B, Bertini R, Di Giulio AM. Reparixin, an inhibitor of CXCR2 function, attenuates inflammatory responses and promotes recovery of function after traumatic lesion to the spinal cord. J Pharmacol Exp Ther. 2007;322:973-81.

185. Impellizzeri D, Mazzon E, Paterniti I, Esposito E, Cuzzocrea S. Effect of fasudil, a selective inhibitor of rho kinase activity, in the secondary injury associated with the experimental model of spinal cord trauma. J Pharmacol Exp Ther. 2012;343:21-33.

186. Li J, Jia Z, Zhang Q, Dai J, Kong J, Fan Z, Li G. Inhibition of ERK1/2 phosphorylation attenuates spinal cord injury induced astrocyte activation and inflammation through negatively regulating aquaporin-4 in rats. Brain Res Bull. 2021;170:162-73.

187. Xu J, Xiao-Qiang E, Liu HY, Tian J, Yan JL. Angelica sinensis attenuates inflammatory reaction in experimental rat models having spinal cord injury. Int J Clin Exp Pathol. 2015;8:6779-85.

188. Pei JP, Fan LH, Nan K, Li J, Dang XQ, Wang KZ. HSYA alleviates secondary neuronal death through attenuating oxidative stress, inflammatory response, and neural apoptosis in SD rat spinal cord compression injury. J Neuroinflamm. 2017;14:97.

189. Cizkova D, Cubinkova V, Smolek T, Murgoci AN, Danko J, Vdoviakova K, Humenik F, Cizek M, Quanico J, Fournier I, Salzet M. Localized intrathecal delivery of mesenchymal stromal cells conditioned medium improves functional recovery in a rat model of spinal cord injury. Int J Mol Sci. 2018;19:870.

\section{Publisher's Note}

Springer Nature remains neutral with regard to jurisdictional claims in published maps and institutional affiliations.
Ready to submit your research? Choose BMC and benefit from:

- fast, convenient online submission

- thorough peer review by experienced researchers in your field

- rapid publication on acceptance

- support for research data, including large and complex data types

- gold Open Access which fosters wider collaboration and increased citations

- maximum visibility for your research: over $100 \mathrm{M}$ website views per year

At BMC, research is always in progress.

Learn more biomedcentral.com/submissions 